\title{
NEW CATALOGUE OF CONDITIONS THAT MAY REQUIRE PEDIATRIC PALLIATIVE CARE
}

\author{
NOWY KATALOG SCHORZEŃ MOGĄCYCH WYMAGAĆ PEDIATRYCZNEJ \\ OPIEKI PALIATYWNEJ
}

\begin{abstract}
${ }^{1}$ The Warsaw Hospice for Children Foundation, Tadeusz Dąbrowski Research and Training Center
${ }^{2}$ National Cancer Registry, Maria Sklodowska-Curie National Research Institute of Oncology ${ }^{1}$ Fundacja Warszawskie Hospicjum dla Dzieci, Centrum Naukowo-Szkoleniowe im. Tadeusza Dąbrowskiego ${ }^{2}$ Krajowy Rejestr Nowotworów, Narodowy Instytut Onkologii im. Marii Skłodowskiej-Curie - Państwowy Instytut Badawczy
\end{abstract}

\begin{abstract}
BACKGROUND. Pediatric palliative care applies to the conditions specified in the Regulation of the Minister of Health. The previous studies have proved that the conditions' catalogue is incomplete and inadequate.

AIM OF STUDY. The aim of the study was to verify completeness and adequacy of the Minister of Health's catalogue and to develop a new catalogue based on available epidemiological data concerning the Polish population.

MATERIALS AND METHODS. The data of the Statistics Poland on underlying causes of death of children (0-17 years old) and young adults (18-29 years old) who died in 1999-2018 were analyzed. Besides, the study includes data collected by the Warsaw Hospice for Children Foundation on diagnoses of 739 patients treated in 1994-2019, including 519 deceased. The catalogue developed on that basis was compared with the Minister of Health's catalogue.

RESULTS. The new catalogue of conditions that may require pediatric palliative care in Poland and the additional criteria of patient recruitment were developed. The incompleteness and inadequacy of the Minister of Health's catalogue were demonstrated.

CONCLUSIONS. The Regulation of the Minister of Health necessitates an amendment regarding the list of medical conditions entitling children to guaranteed palliative care and hospice services. The Minister of Health should introduce standards and medical procedures for pediatric palliative care. Patients should be recruited on the basis of recognized standards by physicians and not officials of the National Health Fund using incomplete and inadequate Minister of Health's catalogue of medical conditions.
\end{abstract}

Key words: children, palliative care, hospice, health policy, epidemiology

\section{STRESZCZENIE}

WSTEPP. Pediatryczna opieka paliatywna dotyczy grupy schorzeń wymienionych w rozporządzeniu Ministra Zdrowia. Wcześniejsze badania wykazały, że katalog tych schorzeń jest niekompletny i nieadekwatny.

CEL PRACY. Celem badania było zweryfikowanie kompletności i adekwatności katalogu Ministra Zdrowia oraz opracowanie nowego katalogu na podstawie dostępnych danych epidemiologicznych dotyczących polskiej populacji.

MATERIAŁ I METODY. Analizowano dane GUS o przyczynach wyjściowych zgonu dzieci w wieku 0-17 lat oraz młodych dorosłych w wieku 18-29 lat zmarłych w okresie 1999-2018. Ponadto uwzględniono dane o rozpoznaniach 739 pacjentów Warszawskiego Hospicjum dla Dzieci leczonych w okresie 1994-2019, w tym 519 zmarłych. Opracowany na tej podstawie katalog schorzeń porównano z katalogiem Ministra Zdrowia. 
WYNIKI. Opracowano nowy katalog schorzeń mogących wymagać pediatrycznej opieki paliatywnej w Polsce oraz kryteria dodatkowe służące kwalifikacji pacjentów. Wykazano niekompletność i nieadekwatność katalogu Ministra Zdrowia w zakresie określonych schorzeń.

WNIOSKI. Rozporządzenie Ministra Zdrowia wymaga nowelizacji w zakresie wykazu jednostek chorobowych kwalifikujących dzieci do świadczeń gwarantowanych z zakresu opieki paliatywnej i hospicyjnej. Minister Zdrowia powinien wprowadzić standardy postępowania i procedury medyczne pediatrycznej opieki paliatywnej. O kwalifikacji pacjentów powinni decydować lekarze na podstawie obowiązujących standardów, a nie urzędnicy Narodowego Funduszu Zdrowia na podstawie niekompletnego i nieadekwatnego katalogu schorzeń Ministra Zdrowia.

Słowa kluczowe: dzieci, opieka paliatywna, hospicjum, polityka zdrowotna, epidemiologia

\section{INTRODUCTION}

Pediatric palliative care (PedPC) provides children with incurable diseases, at high risk of premature death or suffering from symptoms difficult to control, with a seven days a week and round-the-clock medical and nursing care. Its goal is to preserve child's dignity, to improve the quality of his/her life, and to protect her/ him against futile medical care and iatrogenic treatment. It includes symptom management in the child, as well as psychological, social, and spiritual support provided to the whole family, also in form of bereavement care (1). This relatively new field of pediatrics was initiated in Poland by establishment of the Warsaw Hospice for Children (1994) and Department of Palliative Care at the Institute of Mother and Child in Warsaw (1996). The first epidemiological study was published in 2000 (2).

The Supreme Chamber of Control (SCC) reported discrimination in access to palliative and hospice care (PHC) of adult patients with conditions not listed in the Regulation of the Minister of Health (RMH) $(3,4)$.

Our previous research shows that this problem concerns also PHC for children, in other words PedPC, because the RMH catalogue of conditions qualifying for guaranteed services in the scope of PHC (hereafter: $\mathrm{MH}$ catalogue) is incomplete and inadequate (5). Besides, it does not provide information about research on the basis of which it was developed.

The RMH defines those conditions as "incurable, refractory to causal treatment, progressive, lifelimiting". WHO uses in this context two terms: lifethreatening and life-limiting (6). The Polish Pediatric Society has proposed use of the term "incurable medical condition leading to premature death" as a synonym of life-limiting condition (7). Literal translation of the latter term into Polish does not reflect precisely its original meaning and has not been used in Polish language.

The RMH contains a record saying that an adult beneficiary may receive guaranteed PedPC benefits provide that:

a) disease entity is congenital in nature or lifelimiting condition was diagnosed before the age of 18

\section{WSTĘP}

Pediatryczna opieka paliatywna (PedOP) polega na zapewnieniu całodobowych świadczeń lekarskich i pielęgniarskich dzieciom z chorobami nieuleczalnymi, obarczonym wysokim ryzykiem przedwczesnej śmierci, lub cierpiącym z powodu trudnych do opanowania objawów. Ma na celu ochronę godności dziecka, poprawę jakości jego życia, ochronę przed uporczywą terapią i działaniami jatrogennymi. Obejmuje leczenie objawowe dziecka oraz wsparcie psychologiczne, socjalne i duchowe udzielane całej rodzinie, także w okresie żałoby (1). W Polsce ta stosunkowo nowa dziedzina pediatrii została zapoczątkowana powstaniem Warszawskiego Hospicjum dla Dzieci (1994) i Zakładu Opieki Paliatywnej (1996) w Instytucie Matki i Dziecka. Pierwsze badanie epidemiologiczne opublikowano w 2000 r. (2).

Najwyższa Izba Kontroli (NIK) wskazała na dyskryminację w dostępie do opieki paliatywnej i hospicyjnej $(\mathrm{OPH})$ dorosłych pacjentów ze schorzeniami niewymienionymi w rozporządzeniu Ministra Zdrowia (RMZ) $(3,4)$.

Z naszych wcześniejszych badań wynika, że problem ten dotyczy także OPH nad dziećmi, czyli PedOP, ponieważ wykaz jednostek chorobowych RMZ kwalifikujących dzieci do świadczeń gwarantowanych z zakresu OPH (dalej: katalog MZ) jest niekompletny i nieadekwatny (5). Ponadto nie zawiera informacji o badaniach, na podstawie których go opracowano.

RMZ definiuje te schorzenia jako „nieuleczalne, niepoddające się leczeniu przyczynowemu, postępujące, ograniczające życie". WHO używa w tym kontekście dwóch określeń: life-threatening i life-limiting (6). Polskie Towarzystwo Pediatryczne proponuje stosowanie określenia „nieuleczalna choroba prowadząca do przedwczesnej śmierci", jako polskiego synonimu life-limiting condition (7). Dosłowne tłumaczenie tego ostatniego terminu jako, ,schorzenie ograniczające życie" nie oddaje precyzyjnie jego pierwotnego znaczenia i nie było wcześniej używane w języku polskim.

RMZ zawiera zapis mówiący, że świadczeniobiorcy dorosłemu mogą być udzielane świadczenia gwarantowane w ramach opieki paliatywnej dla dzieci, jeżeli: 
years and the beneficiary was receiving guaranteed PedPC benefits provided by a home care hospice for children when he or she was under 18 years or

b) there is no possibility of adequate provision of guaranteed services by home care hospices for adults because of the rare nature of the disease or place of residence.

\section{AIM OF STUDY}

The aim of the study was to verify completeness and adequacy of the Minister of Health catalogue and to develop a new catalogue based on available epidemiological data concerning the Polish population.

\section{MATERIALS AND METHODS}

The data of the Statistics Poland on underlying causes of death (ICD-10 codes) of children ( $0-17$ years old) and young adults (18-29 years old) who died in 1999-2018 were analyzed. Besides, the study includes data collected by the Warsaw Hospice for Children Foundation on diagnoses (ICD-10 codes) of 739 patients treated in 1994-2019, including 519 deceased.

The following inclusion criteria to the catalogue were adopted: the disease is chronic and leads to chronic sequelae, the disease occurs in children (0-17 years), it was a cause of death at the age of 0-29 years in 1999-2018. In the catalogue of underlying (primal) causes of death the very rare diseases and deaths, and garbage codes were omitted. The use of the latter ones proved necessary for coding some additional criteria to qualify patients. The catalogue developed on that basis was compared with the MH catalogue.

The set of selected ICD-10 codes was compared with the list of diseases which, in the case of high risk of premature death, may qualify a child for PedPC, published by the Warsaw Hospice for Children Foundation (WHCF) (1).

It was taken into consideration that an underlying (primal) cause of death (i.e. an early disease process that led to death, or an injury or poisoning that resulted in death) may not be the same as clinical diagnosis which is the basis for the patient's referral to pediatric PHC

It has been taken into account that in rare cases no diagnosis can be made in a child requiring PHC. This applies to so-called syndrome without a name (SWAN) (8).

\section{RESULTS}

The new catalogue of selected conditions that may require PedPC in Poland and the additional criteria of patient recruitment were presented in Table I. It does a) jednostka chorobowa ma charakter wrodzony lub choroba ograniczająca życie została zdiagnozowana przed ukończeniem przez świadczeniobiorcę 18. roku życia, a świadczeniobiorca korzystał ze świadczeń gwarantowanych realizowanych $\mathrm{w}$ hospicjum domowym dla dzieci do ukończenia 18. roku życia lub

b) nie istnieje możliwość odpowiedniego udzielania świadczeń gwarantowanych przez hospicja domowe dla dorosłych ze względu na rzadki charakter choroby lub miejsce zamieszkania.

\section{CEL PRACY}

Celem badania było zweryfikowanie kompletności i adekwatności katalogu MZ oraz opracowanie nowego katalogu na podstawie dostępnych danych epidemiologicznych dotyczących polskiej populacji.

\section{MATERIAŁ I METODY}

Analizowano dane GUS o przyczynach wyjściowych zgonu (kody ICD-10) dzieci w wieku 0-17 lat oraz młodych dorosłych w wieku 18-29 lat zmarłych w okresie 1999-2018. Ponadto uzyskano dane o rozpoznaniach (kody ICD-10) 739 pacjentów Warszawskiego Hospicjum dla Dzieci leczonych w okresie 1994-2019, w tym 519 zmarłych.

Przyjęto następujące kryteria włączenia do katalogu: choroba jest przewlekła lub prowadzi do przewlekłych następstw, występuje u dzieci (0-17 lat), była przyczyną zgonów w wieku 0-29 lat w latach 1999-2018. W katalogu wyjściowych (pierwotnych) przyczyn zgonu pominięto choroby i zgony bardzo rzadkie oraz rozpoznania typu garbage codes (kody bezużyteczne). Użycie tych ostatnich okazało się niezbędne do kodowania niektórych kryteriów dodatkowych, służących kwalifikacji pacjentów. Opracowany katalog schorzeń porównano z katalogiem MZ.

Zbiór wybranych kodów ICD-10 porównano z listą chorób, które w razie wystąpienia ryzyka przedwczesnej śmierci dziecka, mogą kwalifikować do pediatrycznej domowej opieki paliatywnej - opublikowanej przez Fundację Warszawskie Hospicjum dla Dzieci (FWHD) (1).

Wzięto pod uwagę, że wyjściowa (pierwotna) przyczyna zgonu (tj. choroba będąca początkiem procesu chorobowego, który doprowadził do zgonu, albo uraz lub zatrucie, w wyniku którego nastąpił zgon), może nie być tożsama z rozpoznaniem klinicznym, które stanowi podstawę skierowania pacjenta do pediatrycznej OPH.

Uwzględniono, że w rzadkich przypadkach nie można postawić rozpoznania u dziecka wymagającego OPH. Dotyczy to tzw. zespołów chorobowych bez nazwy (ang. syndrome without a name, SWAN) (8). 
not include a number of rare diseases which do not have specific ICD-10 codes. For this reason, it cannot be treated as a closed set.

The incompleteness and inadequacy of $\mathrm{MH}$ catalogue of disease entities qualifying children for PHC were demonstrated identifying:

ICD-10 codes not listed in the MH catalogue which were positively verified: D18.0, D21, E10.7, E34.8, E66.2, G31.8, G31.9, G37.8, G37.9, G40.9, I27.0, I27.2, I27.8，I42.0，I42.1，I42.2，I42.4，I42.5，I42.8， I42.9, P20, P37.1, P52, P96.0, Q26.2-Q26.4, Q26.8, Q26.9, Q28.0-Q28.3, Q33.0，Q33.3，Q33.6-Q33.9，Q43.1, Q61.3, Q61.4, Q86.0, T75.1, T86, W75, W78, W79, W80;

ICD-10 codes listed in the $\mathrm{MH}$ catalogue which were negatively verified (Table II).

\section{DISCUSSION}

The RMH conditions the implementation of PHC benefits by issuing a referral by a physician and by a medical indication, and in particular, the presence of a disease entity in the beneficiary, referred to in Annex 1 to the RMH, with no hope of recovery. That formal limitation led to discrimination in access to PHC, indicated by the SCC, of adult patients with conditions not listed in the RMH.

The effects of that provision on the ground of PedPC should be considered differently. They are of two kinds. First, as in adults, access to services is limited due to incompleteness of $\mathrm{MH}$ catalogue. Second, because of the inadequacy of MH catalogue and the lack of detailed eligibility criteria for PedPC (such criteria are not included in the RMH) children who require longterm care (not palliative one) are allowed to be admitted to hospice services reimbursed by the National Health Fund. In the process of qualifying a patient for PedPC it is important to distinguish patients who really need it because of symptoms difficult to control and endstage organ failure, from those who may be covered in the current phase of the disease by long-term care.

Detailed analysis of the MH catalogue showed that it contains many conditions which do not cause deaths of children or the number of deaths is insignificant (Table II). A certain group of diseases listed in that catalog requires neither palliative nor long-term care.

The category "insignificant number of deaths in children" used in Table II means that in rare cases, patients with these conditions may qualify for PedPC, however, most of them do not require it.

Eligibility criteria for PedPC and discharge patients from home care hospice for children, moreover definitions of PedPC and pediatric long-term care and criteria that differentiate them were published in the WHCF project of standards (1).

\section{WYNIKI}

Nowy katalog wybranych jednostek chorobowych, w przebiegu których może wystąpić potrzeba PedOP oraz kryteria dodatkowe, służące kwalifikacji pacjentów, przedstawiono w Tabeli I. Nie obejmuje on szeregu chorób rzadkich, które nie posiadają specyficznych kodów ICD-10. Z tego powodu nie może być traktowany jako zbiór zamknięty.

Wykazano niekompletność i nieadekwatność katalogu jednostek chorobowych MZ kwalifikujących dzieci do OPH identyfikując:

kody ICD-10 niewystępujące w katalogu MZ, które zostały pozytywnie zweryfikowane: D18.0, D21, E10.7, E34.8, E66.2, G31.8, G31.9, G37.8, G37.9, G40.9, I27.0, I27.2, I27.8, I42.0, I42.1, I42.2, I42.4, I42.5, I42.8, I42.9, P20, P37.1，P52，P96.0, Q26.2-Q26.4, Q26.8, Q26.9, Q28.0-Q28.3, Q33.0, Q33.3, Q33.6-Q33.9, Q43.1, Q61.3, Q61.4, Q86.0, T75.1, T86, W75, W78, W79, W80;

kody ICD-10 występujące w katalogu MZ, które zostały negatywnie zweryfikowane (Tabela II).

\section{DYSKUSJA}

RMZ warunkuje realizację świadczeń OPH wystawieniem przez lekarza skierowania oraz wskazaniem medycznym, a w szczególności faktem występowania u świadczeniobiorcy jednostki chorobowej, o której mowa w załączniku nr 1 do rozporządzenia, nierokującej nadziei na wyleczenie. Właśnie takie formalne ograniczenie doprowadziło do wskazanej przez NIK dyskryminacji w dostępie do OPH pacjentów dorosłych ze schorzeniami niewymienionymi w RMZ.

Inaczej należy rozpatrywać skutki tego przepisu na gruncie PedOP. Są one dwojakiego rodzaju. Po pierwsze, podobnie jak u dorosłych, ogranicza się dostęp do świadczeń z powodu niekompletności katalogu MZ. Po drugie, z powodu nieadekwatności katalogu $\mathrm{MZ}$ oraz braku szczegółowych kryteriów kwalifikacji do PedOP (RMZ takich kryteriów nie zawiera), umożliwia się przyjmowanie do hospicjów dzieci, które wymagają opieki długoterminowej, a nie paliatywnej, oraz refundację tych świadczeń przez Narodowy Fundusz Zdrowia. W procesie kwalifikowania pacjenta do PedOP istotne jest odróżnienie pacjentów, którzy rzeczywiście jej potrzebują z powodu trudnych do opanowania objawów i schyłkowej niewydolności narządów, od tych, którzy w aktualnej fazie choroby mogą zostać objęci opieką długoterminową.

Szczegółowa analiza katalogu MZ wykazała, że zawiera on wiele schorzeń, które nie powodują zgonów dzieci, albo liczba zgonów jest znikoma (Tabela II). Pewna grupa wymienionych w tym katalogu schorzeń nie wymaga ani opieki paliatywnej, ani długoterminowej. 
Table I. Medical conditions that may require pediatric palliative care in Poland and additional criteria of patient recruitment (the new catalogue).

Tabela I. Schorzenia mogące wymagać pediatrycznej opieki paliatywnej w Polsce oraz kryteria dodatkowe, służące kwalifikacji pacjentów (nowy katalog).

\begin{tabular}{|c|c|c|}
\hline \multicolumn{2}{|r|}{$\begin{array}{l}\text { Medical condition } \\
\text { Schorzenie }\end{array}$} & \multirow{2}{*}{$\begin{array}{c}\text { Additional eligibility criteria required } \\
\text { Wymagane dodatkowe kryteria kwalifikacji }\end{array}$} \\
\hline $\begin{array}{l}\text { ICD-10 codes } \\
\text { Kody ICD-10 }\end{array}$ & $\begin{array}{l}\text { Description } \\
\text { Opis }\end{array}$ & \\
\hline $\mathrm{C} 00-\mathrm{C} 14$ & $\begin{array}{l}\text { Malignant neoplasms of lip, oral cavity and } \\
\text { pharynx } \\
\text { Nowotwory złośliwe wargi, jamy ustnej i gardła }\end{array}$ & $\begin{array}{l}\text { Cancer progression despite oncological treatment } \\
\text { Progresja nowotworu mimo leczenia } \\
\text { onkologicznego }\end{array}$ \\
\hline $\begin{array}{l}\mathrm{C} 16-\mathrm{C} 18 \\
\mathrm{C} 22 \\
\mathrm{C} 25-\mathrm{C} 26\end{array}$ & $\begin{array}{l}\text { Malignant neoplasms of digestive organs } \\
\text { Nowotwory złośliwe narządów układu } \\
\text { pokarmowego }\end{array}$ & $\begin{array}{l}\text { Cancer progression despite oncological treatment } \\
\text { Progresja nowotworu mimo leczenia } \\
\text { onkologicznego }\end{array}$ \\
\hline $\begin{array}{l}\text { C30-C38.3, } \\
\text { C38.8, C39 }\end{array}$ & $\begin{array}{l}\text { Malignant neoplasms of respiratory and } \\
\text { intrathoracic organs } \\
\text { Nowotwory złośliwe układu oddechowego } \\
\text { i narządów klatki piersiowej }\end{array}$ & $\begin{array}{l}\text { Cancer progression despite oncological treatment } \\
\text { Progresja nowotworu mimo leczenia } \\
\text { onkologicznego }\end{array}$ \\
\hline $\mathrm{C} 40-\mathrm{C} 41$ & $\begin{array}{l}\text { Malignant neoplasms of bone and articular } \\
\text { cartilage } \\
\text { Nowotwór złośliwy kości i chrząstki stawowej }\end{array}$ & $\begin{array}{l}\text { Cancer progression despite oncological treatment } \\
\text { Progresja nowotworu mimo leczenia } \\
\text { onkologicznego }\end{array}$ \\
\hline C43-C44 & $\begin{array}{l}\text { Melanoma and other malignant neoplasms of skin } \\
\text { Czerniak i inne nowotwory złośliwe skóry }\end{array}$ & $\begin{array}{l}\text { Cancer progression despite oncological treatment } \\
\text { Progresja nowotworu mimo leczenia } \\
\text { onkologicznego }\end{array}$ \\
\hline C45-C49 & $\begin{array}{l}\text { Malignant neoplasms of mesothelial and soft } \\
\text { tissue } \\
\text { Nowotwory złośliwe mezotelium i tkanek } \\
\text { miękkich }\end{array}$ & $\begin{array}{l}\text { Cancer progression despite oncological treatment } \\
\text { Progresja nowotworu mimo leczenia } \\
\text { onkologicznego }\end{array}$ \\
\hline C56 & $\begin{array}{l}\text { Malignant neoplasm of ovary } \\
\text { Nowotwór złośliwy jajnika }\end{array}$ & $\begin{array}{l}\text { Cancer progression despite oncological treatment } \\
\text { Progresja nowotworu mimo leczenia } \\
\text { onkologicznego }\end{array}$ \\
\hline C62-C63 & $\begin{array}{l}\text { Malignant neoplasms of male genital organs } \\
\text { Nowotwory złośliwe męskich narządów } \\
\text { płciowych }\end{array}$ & $\begin{array}{l}\text { Cancer progression despite oncological treatment } \\
\text { Progresja nowotworu mimo leczenia } \\
\text { onkologicznego }\end{array}$ \\
\hline C64-C68 & $\begin{array}{l}\text { Malignant neoplasms of urinary tract } \\
\text { Nowotwory złośliwe układu moczowego }\end{array}$ & $\begin{array}{l}\text { Cancer progression despite oncological treatment } \\
\text { Progresja nowotworu mimo leczenia } \\
\text { onkologicznego }\end{array}$ \\
\hline C69-C72 & $\begin{array}{l}\text { Malignant neoplasms of eye, brain and other parts } \\
\text { of central nervous system } \\
\text { Nowotwory złośliwe oka, mózgu i innych części } \\
\text { ośrodkowego układu nerwowego }\end{array}$ & $\begin{array}{l}\text { Cancer progression despite oncological treatment } \\
\text { Progresja nowotworu mimo leczenia } \\
\text { onkologicznego }\end{array}$ \\
\hline C73-C75 & $\begin{array}{l}\text { Malignant neoplasms of thyroid and other } \\
\text { endocrine glands } \\
\text { Nowotwory złośliwe tarczycy i innych gruczołów } \\
\text { wydzielania wewnętrznego }\end{array}$ & $\begin{array}{l}\text { Cancer progression despite oncological treatment } \\
\text { Progresja nowotworu mimo leczenia } \\
\text { onkologicznego }\end{array}$ \\
\hline C77-C79 & $\begin{array}{l}\text { Malignant neoplasms of ill-defined, other } \\
\text { secondary and unspecified sites Nowotwory } \\
\text { złośliwe niedokładnie określone, wtórne } \\
\text { i o nieokreślonym umiejscowieniu }\end{array}$ & $\begin{array}{l}\text { Cancer progression despite oncological treatment } \\
\text { Progresja nowotworu mimo leczenia } \\
\text { onkologicznego }\end{array}$ \\
\hline C81-C96 & $\begin{array}{l}\text { Malignant neoplasms, stated or presumed to be } \\
\text { primary, of lymphoid, haematopoietic and related } \\
\text { tissue } \\
\text { Nowotwory złośliwe, o potwierdzonym lub } \\
\text { przypuszczalnym pierwotnym charakterze, tkanki } \\
\text { limfatycznej, układu krwiotwórczego i tkanek } \\
\text { pokrewnych }\end{array}$ & $\begin{array}{l}\text { Cancer progression despite oncological treatment } \\
\text { Progresja nowotworu mimo leczenia } \\
\text { onkologicznego }\end{array}$ \\
\hline
\end{tabular}




\begin{tabular}{|c|c|c|}
\hline \multicolumn{2}{|r|}{$\begin{array}{l}\text { Medical condition } \\
\text { Schorzenie }\end{array}$} & \multirow{2}{*}{$\begin{array}{c}\text { Additional eligibility criteria required } \\
\text { Wymagane dodatkowe kryteria kwalifikacji }\end{array}$} \\
\hline $\begin{array}{l}\text { ICD-10 codes } \\
\text { Kody ICD-10 }\end{array}$ & $\begin{array}{c}\text { Description } \\
\text { Opis }\end{array}$ & \\
\hline D18.0 & $\begin{array}{l}\text { Haemangioma (brain) } \\
\text { Naczyniak krwionośny mózgu }\end{array}$ & $\begin{array}{l}\text { I69.1 sequelae of intracerebral haemorrhage } \\
\text { R40.2* persistent vegetative state } \\
\text { I69.1 następstwa krwotoku śródmózgowego } \\
\text { R40.2 stan wegetatywny }\end{array}$ \\
\hline $\begin{array}{l}\text { D33.0, D33.1, } \\
\text { D33.2 }\end{array}$ & $\begin{array}{l}\text { Benign neoplasm of brain } \\
\text { Nowotwór niezłośliwy mózgu }\end{array}$ & $\begin{array}{l}\text { Cancer progression despite oncological treatment } \\
\text { Progresja nowotworu mimo leczenia } \\
\text { onkologicznego }\end{array}$ \\
\hline $\begin{array}{l}\text { D43.0, D43.1, } \\
\text { D43.2 }\end{array}$ & $\begin{array}{l}\text { Neoplasm of uncertain or unknown behaviour of } \\
\text { brain } \\
\text { Nowotwór o niepewnym lub nieznanym } \\
\text { charakterze mózgu }\end{array}$ & $\begin{array}{l}\text { Cancer progression despite oncological treatment } \\
\text { Progresja nowotworu mimo leczenia } \\
\text { onkologicznego }\end{array}$ \\
\hline D46 & $\begin{array}{l}\text { Myelodysplastic syndromes } \\
\text { Zespoły mielodysplastyczne }\end{array}$ & $\begin{array}{l}\text { Cancer progression despite oncological treatment } \\
\text { Progresja nowotworu mimo leczenia } \\
\text { onkologicznego }\end{array}$ \\
\hline E10.7 & $\begin{array}{l}\text { Type } 1 \text { diabetes mellitus with multiple } \\
\text { complications } \\
\text { Cukrzyca insulinozależna z wieloma } \\
\text { powikłaniami }\end{array}$ & $\begin{array}{l}\text { Disease progression, symptoms difficult to control } \\
\text { Progresja choroby, objawy trudne do kontroli }\end{array}$ \\
\hline E34.8 & $\begin{array}{l}\text { Progeria } \\
\text { Progeria }\end{array}$ & $\begin{array}{l}\text { Disease progression, symptoms difficult to control } \\
\text { Progresja choroby, objawy trudne do kontroli }\end{array}$ \\
\hline E66.2 & $\begin{array}{l}\text { Extreme obesity with alveolar hypoventilation } \\
\text { Ciężka otyłość z hipowentylacją pęcherzykową }\end{array}$ & $\begin{array}{l}\text { Disease progression, symptoms difficult to control } \\
\text { Progresja choroby, objawy trudne do kontroli }\end{array}$ \\
\hline $\begin{array}{l}\text { E71-E72, } \\
\text { E74.0, E74.2, } \\
\text { E74.4-E77, } \\
\text { E79.1-E79.9, } \\
\text { E83.0, E84, } \\
\text { E88.8-E88.9 }\end{array}$ & $\begin{array}{l}\text { Metabolic disorders } \\
\text { Choroby metaboliczne }\end{array}$ & $\begin{array}{l}\text { Disease progression, symptoms difficult to control } \\
\text { Progresja choroby, objawy trudne do kontroli }\end{array}$ \\
\hline F84.2 & $\begin{array}{l}\text { Rett syndrome } \\
\text { Zespół Retta }\end{array}$ & $\begin{array}{l}\text { G93.4 encephalopathy, severe form in boys } \\
\text { G93.4 encefalopatia, postać ciężka u chłopców }\end{array}$ \\
\hline G09 & $\begin{array}{l}\text { Sequelae of inflammatory diseases of central } \\
\text { nervous system } \\
\text { Następstwa zapalnych chorób ośrodkowego } \\
\text { układu nerwowego }\end{array}$ & $\begin{array}{l}\text { R } 40.2^{*} \text { persistent vegetative state or G93.4 } \\
\text { encephalopathy } \\
\text { R40.2 stan wegetatywny lub G93.4 encefalopatia }\end{array}$ \\
\hline G10 & $\begin{array}{l}\text { Huntington disease } \\
\text { Pląsawica [choroba Huntingtona] }\end{array}$ & $\begin{array}{l}\text { Juvenile form } \\
\text { Postać młodzieńcza }\end{array}$ \\
\hline G11.1 & $\begin{array}{l}\text { Early-onset cerebellar ataxia } \\
\text { Ataksja móżdżkowa o wczesnym początku }\end{array}$ & $\begin{array}{l}\text { Disease progression, symptoms difficult to control } \\
\text { Progresja choroby, objawy trudne do kontroli }\end{array}$ \\
\hline G11.3 & $\begin{array}{l}\text { Cerebellar ataxia with defective DNA repair } \\
\text { Ataksja móżdżkowa z uszkodzonym systemem } \\
\text { naprawy DNA }\end{array}$ & $\begin{array}{l}\text { Disease progression, symptoms difficult to control } \\
\text { Progresja choroby, objawy trudne do kontroli }\end{array}$ \\
\hline G12.0 & $\begin{array}{l}\text { Infantile spinal muscular atrophy, type } \\
\text { I [Werdnig-Hoffman] } \\
\text { Rdzeniowy zanik mięśni, postać dziecięca, typ } \\
\text { I Werdniga-Hoffmana }\end{array}$ & $\begin{array}{l}\text { J96.1 chronic respiratory failure } \\
\text { J96.1 przewlekła niewydolność oddechowa }\end{array}$ \\
\hline $\begin{array}{l}\text { G12.1, G12.2, } \\
\text { G12.8, G12.9 }\end{array}$ & $\begin{array}{l}\text { Muscular atrophy } \\
\text { Zaniki mięśni }\end{array}$ & $\begin{array}{l}\text { J96.1 chronic respiratory failure } \\
\text { J96.1 przewlekła niewydolność oddechowa }\end{array}$ \\
\hline G23.0 & $\begin{array}{l}\text { Hallervorden-Spatz disease } \\
\text { Choroba Hellervordena-Spatza (choroba } \\
\text { zwyrodnieniowa układu nerwowego związana } \\
\text { z odkładaniem żelaza w mózgu) }\end{array}$ & $\begin{array}{l}\text { Disease progression, symptoms difficult to control } \\
\text { Progresja choroby, objawy trudne do kontroli }\end{array}$ \\
\hline
\end{tabular}




\begin{tabular}{|c|c|c|}
\hline \multicolumn{2}{|r|}{$\begin{array}{l}\text { Medical condition } \\
\quad \text { Schorzenie }\end{array}$} & \multirow{2}{*}{$\begin{array}{c}\text { Additional eligibility criteria required } \\
\text { Wymagane dodatkowe kryteria kwalifikacji }\end{array}$} \\
\hline $\begin{array}{l}\text { ICD-10 codes } \\
\text { Kody ICD-10 }\end{array}$ & $\begin{array}{l}\text { Description } \\
\text { Opis }\end{array}$ & \\
\hline G31.8 & $\begin{array}{l}\text { Subacute necrotizing encephalopathy [Leigh] } \\
\text { Podostra martwicza encefalopatia (zespół Leigha) }\end{array}$ & $\begin{array}{l}\text { Disease progression, symptoms difficult to control } \\
\text { Progresja choroby, objawy trudne do kontroli }\end{array}$ \\
\hline G31.9 & $\begin{array}{l}\text { Degenerative disease of nervous system, } \\
\text { unspecified } \\
\text { Choroby zwyrodnieniowe układu nerwowego, } \\
\text { nieokreślone }\end{array}$ & $\begin{array}{l}\text { Disease progression, symptoms difficult to control } \\
\text { Progresja choroby, objawy trudne do kontroli }\end{array}$ \\
\hline G37.8 & $\begin{array}{l}\text { Other specified demyelinating diseases of central } \\
\text { nervous system } \\
\text { Inne określone choroby demielinizacyjne } \\
\text { ośrodkowego układu nerwowego }\end{array}$ & $\begin{array}{l}\text { Disease progression, symptoms difficult to control } \\
\text { Progresja choroby, objawy trudne do kontroli }\end{array}$ \\
\hline G37.9 & $\begin{array}{l}\text { Demyelinating disease of central nervous system, } \\
\text { unspecified } \\
\text { Choroby demielinizacyjne ośrodkowego układu } \\
\text { nerwowego, nieokreślone }\end{array}$ & $\begin{array}{l}\text { Disease progression, symptoms difficult to control } \\
\text { Progresja choroby, objawy trudne do kontroli }\end{array}$ \\
\hline G40.9 & $\begin{array}{l}\text { Epilepsy, unspecified, intractable (G40.91), } \\
\text { refractory, drug-resistant } \\
\text { Padaczka lekooporna }\end{array}$ & $\begin{array}{l}\text { Disease progression, symptoms difficult to control } \\
\text { Progresja choroby, objawy trudne do kontroli }\end{array}$ \\
\hline $\begin{array}{l}\text { G71, G72.8, } \\
\text { G72.9 }\end{array}$ & $\begin{array}{l}\text { Primary disorders of muscles and other } \\
\text { myopathies } \\
\text { Pierwotne zaburzenia mięśniowe i inne miopatie }\end{array}$ & $\begin{array}{l}\text { J96.1 chronic respiratory failure } \\
\text { J96.1 przewlekła niewydolność oddechowa }\end{array}$ \\
\hline G80 & $\begin{array}{l}\text { Cerebral palsy - most severe form } \\
\text { Mózgowe porażenie dziecięce - postać skrajnie } \\
\text { ciężka }\end{array}$ & $\begin{array}{l}\text { G40.91 epilepsy intractable (drug-resistant) or } \\
\text { J96.1 chronic respiratory failure or E41 or severe } \\
\text { malnutrition with marasmus } \\
\text { G40.9 padaczka lekooporna lub J96.1 przewlekła } \\
\text { niewydolność oddechowa lub E41 ciężkie } \\
\text { niedożywienie z wyniszczeniem }\end{array}$ \\
\hline G91 & $\begin{array}{l}\text { Hydrocephalus - most severe form } \\
\text { Wodogłowie - postać skrajnie ciężka }\end{array}$ & $\begin{array}{l}\text { G40.91 epilepsy intractable (drug-resistant) or } \\
\text { J96.1 chronic respiratory failure or E41 or severe } \\
\text { malnutrition with marasmus } \\
\text { G40.9 padaczka lekooporna lub J96.1 przewlekła } \\
\text { niewydolność oddechowa lub E41 ciężkie } \\
\text { niedożywienie z wyniszczeniem }\end{array}$ \\
\hline G93.1 & $\begin{array}{l}\text { Anoxic brain damage, not elsewhere classified } \\
\text { Uszkodzenie mózgu z niedotlenienia } \\
\text { niesklasyfikowane gdzie indziej }\end{array}$ & $\begin{array}{l}\text { R40.2* persistent vegetative state or G93.4 } \\
\text { encephalopathy, severe form } \\
\text { R40.2 stan wegetatywny lub G93.4 encefalopatia, } \\
\text { postać ciężka }\end{array}$ \\
\hline G93.4 & $\begin{array}{l}\text { Encephalopathy, unspecified } \\
\text { Encefalopatia, nieokreślona }\end{array}$ & $\begin{array}{l}\text { Disease progression, symptoms difficult to control } \\
\text { Progresja choroby, objawy trudne do kontroli }\end{array}$ \\
\hline G93.9 & $\begin{array}{l}\text { Disorder of brain, unspecified } \\
\text { Zaburzenia mózgu, nieokreślone }\end{array}$ & $\begin{array}{l}\text { Disease progression, symptoms difficult to control } \\
\text { Progresja choroby, objawy trudne do kontroli }\end{array}$ \\
\hline I27.0 & $\begin{array}{l}\text { Primary pulmonary hypertension } \\
\text { Pierwotne nadciśnienie płucne }\end{array}$ & $\begin{array}{l}\text { Severe form, symptoms difficult to control } \\
\text { Postać ciężka, objawy trudne do kontroli }\end{array}$ \\
\hline $\mathrm{I} 27.8^{* *}$ & $\begin{array}{l}\text { Eisenmenger’s syndrome } \\
\text { Zespół Eisenmengera }\end{array}$ & $\begin{array}{l}\text { Severe form, symptoms difficult to control } \\
\text { Postać ciężka, objawy trudne do kontroli }\end{array}$ \\
\hline $\begin{array}{l}\mathrm{I} 42.0, \mathrm{I} 42.1 \\
\mathrm{I} 42.2, \mathrm{I} 42.4 \\
\mathrm{I} 42.5, \mathrm{I} 42.8 \\
\mathrm{I} 42.9\end{array}$ & $\begin{array}{l}\text { Cardiomyopathies } \\
\text { Kardiomiopatie }\end{array}$ & $\begin{array}{l}\text { I50 heart failure } \\
\text { I50 niewydolność serca }\end{array}$ \\
\hline
\end{tabular}




\begin{tabular}{|c|c|c|}
\hline \multicolumn{2}{|r|}{$\begin{array}{l}\text { Medical condition } \\
\text { Schorzenie }\end{array}$} & \multirow{2}{*}{$\begin{array}{c}\text { Additional eligibility criteria required } \\
\text { Wymagane dodatkowe kryteria kwalifikacji }\end{array}$} \\
\hline $\begin{array}{l}\text { ICD-10 codes } \\
\text { Kody ICD-10 }\end{array}$ & $\begin{array}{l}\text { Description } \\
\text { Opis }\end{array}$ & \\
\hline $\begin{array}{l}\text { I50, J96, K72, } \\
\text { N18.0 }\end{array}$ & $\begin{array}{l}\text { Irreversible multiple organ dysfunction while } \\
\text { awaiting transplantation } \\
\text { Nieodwracalna niewydolność wielonarządowa } \\
\text { w okresie oczekiwania na przeszczep }\end{array}$ & $\begin{array}{l}\text { A patient who was qualified for transplantation } \\
\text { or retransplantation developed irreversible } \\
\text { complications that exclude further transplantation } \\
\text { effort } \\
\text { Pacjent, który był dotąd zakwalifikowany do } \\
\text { transplantacji lub retransplantacji narządowej, } \\
\text { rozwinął takie nieodwracalne powikłania, które } \\
\text { czynią tę transplantację niemożliwą }\end{array}$ \\
\hline I69 & $\begin{array}{l}\text { Sequelae of cerebrovascular disease } \\
\text { Następstwa chorób naczyniowych mózgu }\end{array}$ & $\begin{array}{l}\text { R } 40.2 * \text { persistent vegetative state } \\
\text { R40.2 stan wegetatywny }\end{array}$ \\
\hline N18.0 & $\begin{array}{l}\text { End-stage renal failure } \\
\text { Schyłkowa niewydolność nerek }\end{array}$ & $\begin{array}{l}\text { Permanent contraindications to chronic dialysis } \\
\text { therapy and kidney transplantation } \\
\text { Trwałe przeciwwskazania do przewlekłej } \\
\text { dializoterapii i transplantacji nerki }\end{array}$ \\
\hline $\begin{array}{l}\text { P10, } \\
\text { P11.0-P11.2, } \\
\text { P11.9 }\end{array}$ & $\begin{array}{l}\text { Birth injury } \\
\text { Uraz okołoporodowy }\end{array}$ & $\begin{array}{l}\text { G93.4 encephalopathy, severe form } \\
\text { G93.4 encefalopatia, postać ciężka }\end{array}$ \\
\hline $\mathrm{P} 20$ & $\begin{array}{l}\text { Intrauterine hypoxia } \\
\text { Niedotlenienie wewnątrzmaciczne }\end{array}$ & $\begin{array}{l}\text { P91.6 encephalopathy, severe form } \\
\text { P91.6 encefalopatia, postać ciężka }\end{array}$ \\
\hline P21 & $\begin{array}{l}\text { Birth asphyxia } \\
\text { Zamartwica urodzeniowa }\end{array}$ & $\begin{array}{l}\text { P91.6 encephalopathy, severe form } \\
\text { P91.6 encefalopatia, postać ciężka }\end{array}$ \\
\hline P27 & $\begin{array}{l}\text { Chronic respiratory disease originating in the } \\
\text { perinatal period } \\
\text { Przewlekła choroba oddechowa rozpoczynająca } \\
\text { się w okresie okołoporodowym }\end{array}$ & $\begin{array}{l}\text { J96.1 chronic respiratory failure } \\
\text { J96.1 przewlekła niewydolność oddechowa }\end{array}$ \\
\hline P35.1 & $\begin{array}{l}\text { Congenital cytomegalovirus infection } \\
\text { Wrodzone zakażenie wywołane przez wirus } \\
\text { cytomegalii }\end{array}$ & $\begin{array}{l}\text { G93.4 encephalopathy, severe form } \\
\text { G93.4 encefalopatia, postać ciężka }\end{array}$ \\
\hline P37.1 & $\begin{array}{l}\text { Congenital toxoplasmosis } \\
\text { Wrodzona toksoplazmoza }\end{array}$ & $\begin{array}{l}\text { G93.4 encephalopathy, severe form } \\
\text { G93.4 encefalopatia, postać ciężka }\end{array}$ \\
\hline P52 & $\begin{array}{l}\text { Intracranial nontraumatic haemorrhage of fetus } \\
\text { and newborn } \\
\text { Śródczaszkowy nieurazowy krwotok u płodu } \\
\text { i noworodka }\end{array}$ & $\begin{array}{l}\text { G93.4 encephalopathy, severe form } \\
\text { G93.4 encefalopatia, postać ciężka }\end{array}$ \\
\hline P91.6 & $\begin{array}{l}\text { Hypoxic ischaemic encephalopathy of newborn } \\
\text { Encefalopatia noworodka z niedotlenienia } \\
\text { niedokrwiennego }\end{array}$ & $\begin{array}{l}\text { Severe form, symptoms difficult to control } \\
\text { Postać ciężka, objawy trudne do kontroli }\end{array}$ \\
\hline P96.0 & $\begin{array}{l}\text { Congenital renal failure } \\
\text { Wrodzona niewydolność nerek }\end{array}$ & $\begin{array}{l}\text { Permanent contraindications to chronic dialysis } \\
\text { therapy and kidney transplantation } \\
\text { Trwałe przeciwwskazania do przewlekłej } \\
\text { dializoterapii i transplantacji nerki }\end{array}$ \\
\hline $\begin{array}{l}\text { Q00-Q04.3, } \\
\text { Q04.5-Q06.1, } \\
\text { Q06.8-Q07 }\end{array}$ & $\begin{array}{l}\text { Congenital malformations of the nervous system } \\
\text { Wrodzone wady rozwojowe układu nerwowego }\end{array}$ & $\begin{array}{l}\text { Severe form, symptoms difficult to control } \\
\text { Postać ciężka, objawy trudne do kontroli }\end{array}$ \\
\hline $\begin{array}{l}\text { Q20-Q23, } \\
\text { Q24.2-Q24.9, } \\
\text { Q25.1-Q25.9, } \\
\text { Q26.2-Q26.4, } \\
\text { Q26.8, Q26.9 }\end{array}$ & $\begin{array}{l}\text { Congenital malformations of the circulatory } \\
\text { system } \\
\text { Wrodzone wady rozwojowe układu krążenia }\end{array}$ & $\begin{array}{l}\text { In end-stage, I50 heart failure or I27.0 primary } \\
\text { pulmonary hypertension or I27.2 secondary } \\
\text { pulmonary hypertension or I27.8 Eisenmenger’s } \\
\text { syndrome } \\
\text { W schyłkowym stadium, I } 50 \text { niewydolność serca } \\
\text { lub I27.0 pierwotne nadciśnienie płucne lub I } 27.2 \\
\text { nadciśnienie płucne wtórne lub I27.8 zespół } \\
\text { Eisenmengera }\end{array}$ \\
\hline
\end{tabular}




\begin{tabular}{|c|c|c|}
\hline \multicolumn{2}{|r|}{$\begin{array}{l}\text { Medical condition } \\
\text { Schorzenie }\end{array}$} & \multirow{2}{*}{$\begin{array}{c}\text { Additional eligibility criteria required } \\
\text { Wymagane dodatkowe kryteria kwalifikacji }\end{array}$} \\
\hline $\begin{array}{l}\text { ICD-10 codes } \\
\text { Kody ICD-10 }\end{array}$ & $\begin{array}{l}\text { Description } \\
\text { Opis }\end{array}$ & \\
\hline Q28.0-Q28.3 & $\begin{array}{l}\text { Congenital malformations of precerebral and } \\
\text { cerebral vessels } \\
\text { Wady rozwojowe naczyń przedmózgowych } \\
\text { i mózgowych }\end{array}$ & $\begin{array}{l}\text { Severe form, symptoms difficult to control } \\
\text { Postać ciężka, objawy trudne do kontroli }\end{array}$ \\
\hline $\begin{array}{l}\text { Q33.0, Q33.3, } \\
\text { Q33.6-Q33.9 }\end{array}$ & $\begin{array}{l}\text { Congenital malformations of lung } \\
\text { Wrodzone wady rozwojowe płuc }\end{array}$ & $\begin{array}{l}\text { Severe form, symptoms difficult to control } \\
\text { Postać ciężka, objawy trudne do kontroli }\end{array}$ \\
\hline Q43.1 & $\begin{array}{l}\text { Hirschsprung disease } \\
\text { Choroba Hirschsprunga }\end{array}$ & $\begin{array}{l}\text { Severe form, symptoms difficult to control } \\
\text { Postać ciężka, objawy trudne do kontroli }\end{array}$ \\
\hline Q44.7 & $\begin{array}{l}\text { Alagille syndrom } \\
\text { Zespół Alagille’a }\end{array}$ & $\begin{array}{l}\text { Severe form, symptoms difficult to control } \\
\text { Postać ciężka, objawy trudne do kontroli }\end{array}$ \\
\hline $\begin{array}{l}\text { Q60.1, Q60.4, } \\
\text { Q60.6, Q61.1, } \\
\text { Q61.3, Q61.4 }\end{array}$ & $\begin{array}{l}\text { Congenital malformations of kidney } \\
\text { Wrodzone wady rozwojowe nerek }\end{array}$ & $\begin{array}{l}\text { N18.0, permanent contraindications to chronic } \\
\text { dialysis therapy and kidney transplantation } \\
\text { N18.0, obecność trwałych przeciwwskazań do } \\
\text { przewlekłej dializoterapii i transplantacji nerki }\end{array}$ \\
\hline $\begin{array}{l}\text { Q77.1, Q77.4, } \\
\text { Q77.8 }\end{array}$ & $\begin{array}{l}\text { Osteochondrodysplasia } \\
\text { Dysplazja kostno-chrzęstna }\end{array}$ & $\begin{array}{l}\text { Severe form, symptoms difficult to control } \\
\text { Postać ciężka, objawy trudne do kontroli }\end{array}$ \\
\hline Q78.0 & $\begin{array}{l}\text { Osteogenesis imperfecta } \\
\text { Wrodzona łamliwość kości }\end{array}$ & $\begin{array}{l}\text { Type } 2 \text { or } 3 \\
\text { Typ } 2 \text { lub } 3\end{array}$ \\
\hline Q81.1 & $\begin{array}{l}\text { Epidermolysis bullosa letalis, Herlitz syndrome } \\
\text { Pęcherzowe oddzielanie naskórka, postać } \\
\text { śmiertelna, typ Herlitza }\end{array}$ & \\
\hline Q85 & $\begin{array}{l}\text { Phakomatoses } \\
\text { Fakomatozy }\end{array}$ & $\begin{array}{l}\text { Severe form, symptoms difficult to control } \\
\text { Postać ciężka, objawy trudne do kontroli }\end{array}$ \\
\hline Q86.0 & $\begin{array}{l}\text { Fetal alcohol syndrome (dysmorphic) } \\
\text { Płodowy zespół alkoholowy }\end{array}$ & $\begin{array}{l}\text { Severe form, symptoms difficult to control } \\
\text { Postać ciężka, objawy trudne do kontroli }\end{array}$ \\
\hline Q86.8 & $\begin{array}{l}\text { Other congenital malformation syndromes due to } \\
\text { known exogenous causes } \\
\text { Inne (letalne) zespoły wrodzonych wad } \\
\text { rozwojowych spowodowane przez znane czynniki } \\
\text { zewnętrzne }\end{array}$ & $\begin{array}{l}\text { Severe form, symptoms difficult to control } \\
\text { Postać ciężka, objawy trudne do kontroli }\end{array}$ \\
\hline Q87.1 & $\begin{array}{l}\text { Smith-Lemli-Opitz syndrome } \\
\text { Zespół Smitha-Lemliego-Opitza }\end{array}$ & $\begin{array}{l}\text { Severe form, symptoms difficult to control } \\
\text { Progresja choroby, objawy trudne do kontroli }\end{array}$ \\
\hline Q87.2 & $\begin{array}{l}\text { VATER/VACTERL syndrome } \\
\text { Zespół VATER lub VACTERL }\end{array}$ & $\begin{array}{l}\text { Severe form, symptoms difficult to control } \\
\text { Postać ciężka, objawy trudne do kontroli }\end{array}$ \\
\hline Q87.5 & $\begin{array}{l}\text { Other congenital malformation syndromes with } \\
\text { other skeletal changes } \\
\text { Inne (letalne) zespoły wrodzonych wad } \\
\text { rozwojowych z innymi zmianami szkieletowymi }\end{array}$ & $\begin{array}{l}\text { Severe form, symptoms difficult to control } \\
\text { Postać ciężka, objawy trudne do kontroli }\end{array}$ \\
\hline Q87.8 & $\begin{array}{l}\text { Zellweger syndrome*** and other specified } \\
\text { congenital malformation syndromes, not } \\
\text { elsewhere classified } \\
\text { Zespół Zellwegera oraz inne określone zespoły } \\
\text { wrodzonych wad rozwojowych niesklasyfikowane } \\
\text { gdzie indziej }\end{array}$ & $\begin{array}{l}\text { Lethal forms } \\
\text { Postacie letalne }\end{array}$ \\
\hline Q89.4 & $\begin{array}{l}\text { Conjoined twins } \\
\text { Bliźnięta zrośnięte }\end{array}$ & $\begin{array}{l}\text { Lethal forms } \\
\text { Postacie letalne }\end{array}$ \\
\hline Q89.7 & $\begin{array}{l}\text { Multiple congenital malformations, not elsewhere } \\
\text { classified } \\
\text { Mnogie wrodzone wady rozwojowe } \\
\text { niesklasyfikowane gdzie indziej }\end{array}$ & $\begin{array}{l}\text { Severe form, symptoms difficult to control } \\
\text { Postać ciężka, objawy trudne do kontroli }\end{array}$ \\
\hline
\end{tabular}




\begin{tabular}{|c|c|c|}
\hline \multicolumn{2}{|r|}{$\begin{array}{l}\text { Medical condition } \\
\text { Schorzenie }\end{array}$} & \multirow{2}{*}{$\begin{array}{c}\text { Additional eligibility criteria required } \\
\text { Wymagane dodatkowe kryteria kwalifikacji }\end{array}$} \\
\hline $\begin{array}{l}\text { ICD-10 codes } \\
\text { Kody ICD-10 }\end{array}$ & $\begin{array}{c}\text { Description } \\
\text { Opis }\end{array}$ & \\
\hline Q90 & $\begin{array}{l}\text { Down syndrome } \\
\text { Zespół Downa }\end{array}$ & $\begin{array}{l}\text { In end-stage, I50 heart failure or I } 27.0 \text { primary } \\
\text { pulmonary hypertension or I27.2 secondary } \\
\text { pulmonary hypertension or I27.8 Eisenmenger's } \\
\text { syndrome } \\
\text { W schyłkowym stadium, I50 niewydolność serca } \\
\text { lub I27.0 pierwotne nadciśnienie płucne lub I } 27.2 \\
\text { nadciśnienie płucne wtórne lub I27.8 zespół } \\
\text { Eisenmengera }\end{array}$ \\
\hline Q91 & $\begin{array}{l}\text { Edwards syndrome and Patau syndrome } \\
\text { Zespół Edwardsa i zespół Pataua }\end{array}$ & \\
\hline Q92 & $\begin{array}{l}\text { Other trisomies and partial trisomies of the } \\
\text { autosomes, not elsewhere classified } \\
\text { Inne trisomie i częściowe trisomie autosomów, } \\
\text { niesklasyfikowane gdzie indziej }\end{array}$ & $\begin{array}{l}\text { Lethal forms (genetic consultation necessary) } \\
\text { Postacie letalne (konieczna konsultacja } \\
\text { genetyczna) }\end{array}$ \\
\hline Q93 & $\begin{array}{l}\text { Monosomies and deletions from the autosomes, } \\
\text { not elsewhere classified } \\
\text { Monosomie i delecje autosomów } \\
\text { niesklasyfikowane gdzie indziej }\end{array}$ & $\begin{array}{l}\text { Lethal forms (genetic consultation necessary) } \\
\text { Postacie letalne (konieczna konsultacja } \\
\text { genetyczna) }\end{array}$ \\
\hline Q99.8, Q99.9 & $\begin{array}{l}\text { Other chromosome abnormalities, not elsewhere } \\
\text { classified } \\
\text { Inne aberracje chromosomalne niesklasyfikowane } \\
\text { gdzie indziej }\end{array}$ & $\begin{array}{l}\text { Lethal forms (genetic consultation necessary) } \\
\text { Postacie letalne (konieczna konsultacja } \\
\text { genetyczna) }\end{array}$ \\
\hline R40.2 & $\begin{array}{l}\text { Coma } \\
\text { Śpiączka }\end{array}$ & $\begin{array}{l}\text { Vegetative state, minimally conscious state } \\
\text { Stan wegetatywny, stan minimalnej świadomości }\end{array}$ \\
\hline S06.7 & $\begin{array}{l}\text { Intracranial injury with prolonged coma } \\
\text { Uraz śródczaszkowy z długotrwałym okresem } \\
\text { nieprzytomności }\end{array}$ & \\
\hline T75.1 & $\begin{array}{l}\text { Drowning and nonfatal submersion } \\
\text { Tonięcie niezakończone zgonem }\end{array}$ & $\begin{array}{l}\text { G93.1 hypoxic brain damage, not elsewhere } \\
\text { classified or R40.2* persistent vegetative state } \\
\text { G93.1 uszkodzenie mózgu z niedotlenienia } \\
\text { niesklasyfikowane gdzie indziej lub R40.2 stan } \\
\text { wegetatywny }\end{array}$ \\
\hline T86 & $\begin{array}{l}\text { Failure and rejection of transplanted organs and } \\
\text { tissues } \\
\text { Niewydolność i odrzucenie przeszczepionych } \\
\text { narządów i tkanek }\end{array}$ & $\begin{array}{l}\text { A patient who was qualified for retransplantation } \\
\text { developed irreversible complications that exclude } \\
\text { further transplantation effort } \\
\text { Pacjent, który był dotąd zakwalifikowany do } \\
\text { retransplantacji narządowej, rozwinął takie } \\
\text { nieodwracalne powikłania, które czynią tę } \\
\text { transplantację niemożliwą }\end{array}$ \\
\hline W75 & $\begin{array}{l}\text { Accidental suffocation and strangulation in bed } \\
\text { Przypadkowe zadławienie i zadzierzgnięcie } \\
\text { w łóżku }\end{array}$ & $\begin{array}{l}\text { G93.1 hypoxic brain damage, not elsewhere } \\
\text { classified or R40.2* persistent vegetative state } \\
\text { G93.1 uszkodzenie mózgu z niedotlenienia } \\
\text { niesklasyfikowane gdzie indziej lub R40.2 stan } \\
\text { wegetatywny }\end{array}$ \\
\hline $\begin{array}{l}\text { W78, W79, } \\
\text { W80 }\end{array}$ & $\begin{array}{l}\text { Inhalation and ingestion causing obstruction of } \\
\text { respiratory tract } \\
\text { Aspiracja powodująca zablokowanie dróg } \\
\text { oddechowych }\end{array}$ & $\begin{array}{l}\text { G93.1 hypoxic brain damage, not elsewhere } \\
\text { classified or R } 40.2^{*} \text { persistent vegetative state } \\
\text { G93.1 uszkodzenie mózgu z niedotlenienia } \\
\text { niesklasyfikowane gdzie indziej lub R } 40.2 \text { stan } \\
\text { wegetatywny }\end{array}$ \\
\hline
\end{tabular}




\begin{tabular}{|c|c|c|}
\hline \multicolumn{2}{|r|}{$\begin{array}{l}\text { Medical condition } \\
\text { Schorzenie }\end{array}$} & \multirow{2}{*}{$\begin{array}{c}\text { Additional eligibility criteria required } \\
\text { Wymagane dodatkowe kryteria kwalifikacji }\end{array}$} \\
\hline $\begin{array}{l}\text { ICD-10 codes } \\
\text { Kody ICD-10 }\end{array}$ & $\begin{array}{l}\text { Description } \\
\text { Opis }\end{array}$ & \\
\hline Y85-Y88 & $\begin{array}{l}\text { Sequelae of external causes of morbidity and } \\
\text { mortality } \\
\text { Następstwa zewnętrznych przyczyn zachorowania } \\
\text { i zgonu }\end{array}$ & $\begin{array}{l}\text { G93.1 hypoxic brain damage, not elsewhere } \\
\text { classified or R40.2* persistent vegetative state } \\
\text { G93.1 uszkodzenie mózgu z niedotlenienia } \\
\text { niesklasyfikowane gdzie indziej lub R } 40.2 \text { stan } \\
\text { wegetatywny }\end{array}$ \\
\hline $\begin{array}{l}\text { No code } \\
\text { Brak kodu }\end{array}$ & $\begin{array}{l}\text { Syndromes without a name (SWAN) } \\
\text { They can possibly be encoded as G93.4 or } \\
\text { G93.9 if unspecified encephalopathy or brain } \\
\text { abnormalities are present } \\
\text { Zespoły chorobowe bez nazwy tzw. SWAN } \\
\text { Można je ewentualnie kodować jako G93.4 lub } \\
\text { G93.9, jeżeli występuje w nich nieokreślona } \\
\text { encefalopatia lub nieokreślone zaburzenia mózgu }\end{array}$ & $\begin{array}{l}\text { Severe form, symptoms difficult to control } \\
\text { Postać ciężka, objawy trudne do kontroli }\end{array}$ \\
\hline
\end{tabular}

*R40.3 ICD-10-CM

**I27.83 ICD-10-CM

***E71.510 ICD-10-CM

See: https://icd10cmtool.cdc.gov/?fy=FY2021

Table II. Medical conditions that may require pediatric palliative care listed in the Minister of Health's catalogue which were negatively verified.

Tabela II. Schorzenia wymienione katalogu jednostek chorobowych MZ kwalifikujących dzieci do OPH, które zostały negatywnie zweryfikowane.

\begin{tabular}{|c|c|c|}
\hline \multicolumn{2}{|r|}{$\begin{array}{l}\text { Medical condition } \\
\text { Schorzenie }\end{array}$} & \multirow{2}{*}{$\begin{array}{l}\text { Reasons for rejection } \\
\text { Przyczyny odrzucenia }\end{array}$} \\
\hline $\begin{array}{l}\text { ICD-10 codes } \\
\text { Kody ICD-10 }\end{array}$ & $\begin{array}{l}\text { Description } \\
\text { Opis }\end{array}$ & \\
\hline A81 & $\begin{array}{l}\text { Atypical virus infections of central nervous } \\
\text { system } \\
\text { Atypowe wirusowe zakażenia ośrodkowego } \\
\text { układu nerwowego }\end{array}$ & $\begin{array}{l}\text { Code appropriate for PHC - G09 Sequelae of } \\
\text { inflammatory diseases of central nervous system } \\
\text { Kod właściwy dla OPH - G09 Następstwa } \\
\text { zapalnych chorób ośrodkowego układu } \\
\text { nerwowego }\end{array}$ \\
\hline B20-B24 & $\begin{array}{l}\text { Diseases caused by the human immunodeficiency } \\
\text { virus [HIV] } \\
\text { Choroba wywołana przez ludzki wirus } \\
\text { upośledzenia odporności [HIV] }\end{array}$ & $\begin{array}{l}\text { No child deaths } \\
\text { Brak zgonów dzieci }\end{array}$ \\
\hline B90-B94 & $\begin{array}{l}\text { Sequelae of infectious and parasitic diseases } \\
\text { Następstwa chorób zakaźnych i pasożytniczych }\end{array}$ & $\begin{array}{l}\text { No child deaths } \\
\text { Brak zgonów dzieci }\end{array}$ \\
\hline $\mathrm{C} 15$ & $\begin{array}{l}\text { Malignant neoplasm of oesophagus } \\
\text { Nowotwór złośliwy przełyku }\end{array}$ & $\begin{array}{l}\text { Insignificant number of deaths in children } \\
\text { Znikoma liczba zgonów dzieci }\end{array}$ \\
\hline C19 & $\begin{array}{l}\text { Malignant neoplasm of rectosigmoid junction } \\
\text { Nowotwór złośliwy żołądka }\end{array}$ & $\begin{array}{l}\text { No child deaths } \\
\text { Brak zgonów dzieci }\end{array}$ \\
\hline $\mathrm{C} 20$ & $\begin{array}{l}\text { Malignant neoplasm of rectum } \\
\text { Nowotwór złośliwy odbytnicy }\end{array}$ & $\begin{array}{l}\text { Insignificant number of deaths in children } \\
\text { Znikoma liczba zgonów dzieci }\end{array}$ \\
\hline $\mathrm{C} 21$ & $\begin{array}{l}\text { Malignant neoplasm of anus and anal canal } \\
\text { Nowotwór złośliwy odbytu i kanału odbytu }\end{array}$ & $\begin{array}{l}\text { No child deaths } \\
\text { Brak zgonów dzieci }\end{array}$ \\
\hline $\mathrm{C} 23$ & $\begin{array}{l}\text { Malignant neoplasm of gallbladder } \\
\text { Nowotwór złośliwy pęcherzyka żółciowego }\end{array}$ & $\begin{array}{l}\text { Insignificant number of deaths in children } \\
\text { Znikoma liczba zgonów dzieci }\end{array}$ \\
\hline $\mathrm{C} 24$ & $\begin{array}{l}\text { Malignant neoplasm of other and unspecified } \\
\text { parts of biliary tract } \\
\text { Nowotwór złośliwy innych i nieokreślonych } \\
\text { części dróg żółciowych }\end{array}$ & $\begin{array}{l}\text { Insignificant number of deaths in children } \\
\text { Znikoma liczba zgonów dzieci }\end{array}$ \\
\hline
\end{tabular}




\begin{tabular}{|c|c|c|}
\hline \multicolumn{2}{|r|}{$\begin{array}{l}\text { Medical condition } \\
\text { Schorzenie }\end{array}$} & \multirow{2}{*}{$\begin{array}{l}\text { Reasons for rejection } \\
\text { Przyczyny odrzucenia }\end{array}$} \\
\hline $\begin{array}{l}\text { ICD-10 codes } \\
\text { Kody ICD-10 }\end{array}$ & $\begin{array}{c}\text { Description } \\
\text { Opis }\end{array}$ & \\
\hline C38.4 & $\begin{array}{l}\text { Malignant neoplasm of pleura } \\
\text { Nowotwór złośliwy opłucnej }\end{array}$ & $\begin{array}{l}\text { Insignificant number of deaths in children } \\
\text { Znikoma liczba zgonów dzieci }\end{array}$ \\
\hline $\mathrm{C} 50$ & \begin{tabular}{|l|} 
Malignant neoplasm of breast \\
Nowotwór złośliwy piersi \\
\end{tabular} & $\begin{array}{l}\text { Insignificant number of deaths in children } \\
\text { Znikoma liczba zgonów dzieci }\end{array}$ \\
\hline C51 & $\begin{array}{l}\text { Malignant neoplasm of vulva } \\
\text { Nowotwór złośliwy sromu }\end{array}$ & $\begin{array}{l}\text { No child deaths } \\
\text { Brak zgonów dzieci }\end{array}$ \\
\hline $\mathrm{C} 52$ & $\begin{array}{l}\text { Malignant neoplasm of vagina } \\
\text { Nowotwór złośliwy pochwy }\end{array}$ & $\begin{array}{l}\text { No child deaths } \\
\text { Brak zgonów dzieci }\end{array}$ \\
\hline $\mathrm{C} 53$ & $\begin{array}{l}\text { Malignant neoplasm of cervix uteri } \\
\text { Nowotwór złośliwy szyjki macicy }\end{array}$ & \begin{tabular}{|l|} 
No child deaths \\
Brak zgonów dzieci
\end{tabular} \\
\hline $\mathrm{C} 54$ & $\begin{array}{l}\text { Malignant neoplasm of corpus uteri } \\
\text { Nowotwór złośliwy trzonu macicy }\end{array}$ & $\begin{array}{l}\text { No child deaths } \\
\text { Brak zgonów dzieci }\end{array}$ \\
\hline $\mathrm{C} 55$ & $\begin{array}{l}\text { Malignant neoplasm of uterus, part unspecified } \\
\text { Nowotwór złośliwy nieokreślonej części macicy }\end{array}$ & $\begin{array}{l}\text { No child deaths } \\
\text { Brak zgonów dzieci }\end{array}$ \\
\hline $\mathrm{C} 57$ & $\begin{array}{l}\text { Malignant neoplasm of other and unspecified } \\
\text { female genital organs } \\
\text { Nowotwór złośliwy innych i nieokreślonych } \\
\text { żeńskich narządów płciowych }\end{array}$ & $\begin{array}{l}\text { No child deaths } \\
\text { Brak zgonów dzieci }\end{array}$ \\
\hline $\mathrm{C} 58$ & $\begin{array}{l}\text { Malignant neoplasm of placenta } \\
\text { Nowotwór złośliwy łożyska }\end{array}$ & \begin{tabular}{|l|} 
No child deaths \\
Brak zgonów dzieci
\end{tabular} \\
\hline C60 & $\begin{array}{l}\text { Malignant neoplasm of penis } \\
\text { Nowotwór złośliwy prącia }\end{array}$ & $\begin{array}{l}\text { No child deaths } \\
\text { Brak zgonów dzieci }\end{array}$ \\
\hline C61 & $\begin{array}{l}\text { Malignant neoplasm of prostate } \\
\text { Nowotwór złośliwy gruczołu krokowego }\end{array}$ & $\begin{array}{l}\text { Insignificant number of deaths in children } \\
\text { Znikoma liczba zgonów dzieci }\end{array}$ \\
\hline $\mathrm{C} 76$ & $\begin{array}{l}\text { Malignant neoplasm of other and ill-defined sites } \\
\text { Nowotwór złośliwy o umiejscowieniu innym } \\
\text { i niedokładnie określonym }\end{array}$ & Garbage code \\
\hline $\mathrm{C} 80$ & $\begin{array}{l}\text { Malignant neoplasm, without specification of site } \\
\text { Nowotwór złośliwy bez określenia } \\
\text { umiejscowienia }\end{array}$ & Garbage code \\
\hline C97 & $\begin{array}{l}\text { Malignant neoplasms of independent (primary) } \\
\text { multiple sites } \\
\text { Nowotwory złośliwe o niezależnym (pierwotnym) } \\
\text { mnogim umiejscowieniu }\end{array}$ & Garbage code \\
\hline D00-D09 & $\begin{array}{l}\text { Carcinoma in situ } \\
\text { Nowotwory in situ }\end{array}$ & $\begin{array}{l}\text { Do not cause death } \\
\text { Nie powodują zgonów }\end{array}$ \\
\hline D32 & $\begin{array}{l}\text { Benign neoplasm of meninges } \\
\text { Nowotwór niezłośliwy opon mózgowo- } \\
\text { rdzeniowych }\end{array}$ & $\begin{array}{l}\text { Insignificant number of deaths in children } \\
\text { Znikoma liczba zgonów dzieci }\end{array}$ \\
\hline D33.3 & $\begin{array}{l}\text { Benign neoplasm of cranial nerves } \\
\text { Nowotwór niezłośliwy. Nerwy czaszkowe }\end{array}$ & $\begin{array}{l}\text { No child deaths } \\
\text { Brak zgonów dzieci }\end{array}$ \\
\hline D33.4 & $\begin{array}{l}\text { Benign neoplasm of spinal cord } \\
\text { Nowotwór niezłośliwy. Rdzeń kręgowy }\end{array}$ & $\begin{array}{l}\text { Insignificant number of deaths in children } \\
\text { Znikoma liczba zgonów dzieci }\end{array}$ \\
\hline D33.7 & $\begin{array}{l}\text { Benign neoplasm of other specified parts of } \\
\text { central nervous system } \\
\text { Nowotwór niezłośliwy. Inne określone części } \\
\text { ośrodkowego układu nerwowego }\end{array}$ & $\begin{array}{l}\text { No child deaths } \\
\text { Brak zgonów dzieci }\end{array}$ \\
\hline D33.9 & $\begin{array}{l}\text { Benign neoplasm of central nervous system, } \\
\text { unspecified } \\
\text { Nowotwór niezłośliwy. Ośrodkowy układ } \\
\text { nerwowy, umiejscowienie nieokreślone }\end{array}$ & $\begin{array}{l}\text { Insignificant number of deaths in children } \\
\text { Znikoma liczba zgonów dzieci }\end{array}$ \\
\hline
\end{tabular}




\begin{tabular}{|c|c|c|}
\hline \multicolumn{2}{|r|}{$\begin{array}{l}\text { Medical condition } \\
\text { Schorzenie }\end{array}$} & \multirow{2}{*}{$\begin{array}{l}\text { Reasons for rejection } \\
\text { Przyczyny odrzucenia }\end{array}$} \\
\hline $\begin{array}{l}\text { ICD-10 codes } \\
\text { Kody ICD-10 }\end{array}$ & $\begin{array}{c}\text { Description } \\
\text { Opis }\end{array}$ & \\
\hline $\begin{array}{l}\text { D37-D42, } \\
\text { D43.3-D45, } \\
\text { D47-D48 }\end{array}$ & $\begin{array}{l}\text { Neoplasm of uncertain or unknown behaviour } \\
\text { Nowotwory o niepewnym lub nieznanym } \\
\text { charakterze }\end{array}$ & $\begin{array}{l}\text { Insignificant number of deaths in children } \\
\text { Znikoma liczba zgonów dzieci }\end{array}$ \\
\hline E70 & $\begin{array}{l}\text { Disorders of aromatic amino-acid metabolism } \\
\text { Zaburzenia przemian aminokwasów } \\
\text { aromatycznych }\end{array}$ & $\begin{array}{l}\text { Insignificant number of deaths in children } \\
\text { Znikoma liczba zgonów dzieci }\end{array}$ \\
\hline E73 & $\begin{array}{l}\text { Lactose intolerance } \\
\text { Nietolerancja laktozy }\end{array}$ & $\begin{array}{l}\text { No child deaths } \\
\text { Brak zgonów dzieci }\end{array}$ \\
\hline E74.1 & $\begin{array}{l}\text { Disorders of fructose metabolism } \\
\text { Zaburzenia przemian fruktozy }\end{array}$ & $\begin{array}{l}\text { No child deaths } \\
\text { Brak zgonów dzieci }\end{array}$ \\
\hline E74.3 & $\begin{array}{l}\text { Other disorders of intestinal carbohydrate } \\
\text { absorption } \\
\text { Inne zaburzenia wchłaniania jelitowego } \\
\text { węglowodanów }\end{array}$ & $\begin{array}{l}\text { No child deaths } \\
\text { Brak zgonów dzieci }\end{array}$ \\
\hline E78 & $\begin{array}{l}\text { Disorders of lipoprotein metabolism and other } \\
\text { lipidaemias } \\
\text { Zaburzenia metabolizmu lipoprotein i inne } \\
\text { lipidemie }\end{array}$ & $\begin{array}{l}\text { Insignificant number of deaths in children } \\
\text { Znikoma liczba zgonów dzieci }\end{array}$ \\
\hline E79.0 & $\begin{array}{l}\text { Hyperuricaemia without signs of inflammatory } \\
\text { arthritis and tophaceous disease } \\
\text { Hiperurykemia bez objawów zapalenia stawów } \\
\text { i obecności guzków dnawych }\end{array}$ & $\begin{array}{l}\text { No child deaths } \\
\text { Brak zgonów dzieci }\end{array}$ \\
\hline E80 & $\begin{array}{l}\text { Disorders of porphyrin and bilirubin metabolism } \\
\text { Zaburzenia przemian porfiryn i bilirubiny }\end{array}$ & $\begin{array}{l}\text { Insignificant number of deaths in children } \\
\text { Znikoma liczba zgonów dzieci }\end{array}$ \\
\hline E83.1-E83.9 & $\begin{array}{l}\text { Disorders of mineral metabolism } \\
\text { Zaburzenia gospodarki mineralnej }\end{array}$ & $\begin{array}{l}\text { Insignificant number of deaths in children } \\
\text { Znikoma liczba zgonów dzieci }\end{array}$ \\
\hline E85 & $\begin{array}{l}\text { Amyloidosis } \\
\text { Amyloidoza [skrobiawica] }\end{array}$ & $\begin{array}{l}\text { Insignificant number of deaths in children } \\
\text { Znikoma liczba zgonów dzieci }\end{array}$ \\
\hline E86 & $\begin{array}{l}\text { Volume depletion } \\
\text { Nadmierna utrata płynów }\end{array}$ & Garbage code \\
\hline E87 & $\begin{array}{l}\text { Other disorders of fluid, electrolyte and acid-base } \\
\text { balance } \\
\text { Inne zaburzenia równowagi wodno-elektrolitowej } \\
\text { i kwasowo-zasadowej }\end{array}$ & $\begin{array}{l}\text { Reversible disorders; the code E87.2 does not } \\
\text { describe metabolic acidosis in the course of } \\
\text { congenital diseases (e.g. fumaric or glutaric } \\
\text { acidosis) } \\
\text { Zaburzenia odwracalne; kod E87.2 nie określa } \\
\text { kwasicy metabolicznej w przebiegu chorób } \\
\text { wrodzonych (np. kwasica fumarowa lub glutarowa) }\end{array}$ \\
\hline E88.0-E88.2 & $\begin{array}{l}\text { Other metabolic disorders } \\
\text { Inne zaburzenia metaboliczne }\end{array}$ & $\begin{array}{l}\text { Insignificant number of deaths in children } \\
\text { Znikoma liczba zgonów dzieci }\end{array}$ \\
\hline E89 & $\begin{array}{l}\text { Postprocedural endocrine and metabolic } \\
\text { disorders, not elsewhere classified } \\
\text { Pozabiegowe zaburzenia wydzielania } \\
\text { wewnętrznego i metaboliczne, niesklasyfikowane } \\
\text { gdzie indziej }\end{array}$ & $\begin{array}{l}\text { No child deaths } \\
\text { Brak zgonów dzieci }\end{array}$ \\
\hline E90 & $\begin{array}{l}\text { Nutritional and metabolic disorders in diseases } \\
\text { classified elsewhere } \\
\text { Zaburzenia odżywiania i metaboliczne } \\
\text { w przebiegu chorób sklasyfikowanych gdzie } \\
\text { indziej }\end{array}$ & $\begin{array}{l}\text { No child deaths } \\
\text { Brak zgonów dzieci }\end{array}$ \\
\hline
\end{tabular}




\begin{tabular}{|c|c|c|}
\hline \multicolumn{2}{|r|}{$\begin{array}{l}\text { Medical condition } \\
\text { Schorzenie }\end{array}$} & \multirow{2}{*}{$\begin{array}{l}\text { Reasons for rejection } \\
\text { Przyczyny odrzucenia }\end{array}$} \\
\hline $\begin{array}{l}\text { ICD-10 codes } \\
\text { Kody ICD-10 }\end{array}$ & $\begin{array}{l}\text { Description } \\
\text { Opis }\end{array}$ & \\
\hline F84 & $\begin{array}{l}\text { Pervasive developmental disorders } \\
\text { Całościowe zaburzenia rozwojowe }\end{array}$ & $\begin{array}{l}\text { No child deaths; long-term care (not applicable } \\
\text { to boys with Rett syndrome and severe } \\
\text { encephalopathy - F84.2) } \\
\text { Brak zgonów dzieci; opieka długoterminowa } \\
\text { (nie dotyczy chłopców z zespołem Retta i ciężką } \\
\text { encefalopatią - F84.2) }\end{array}$ \\
\hline $\begin{array}{l}\text { G11.0, G11.2, } \\
\text { G11.4-G11.9 }\end{array}$ & $\begin{array}{l}\text { Hereditary ataxia } \\
\text { Ataksja dziedziczna }\end{array}$ & $\begin{array}{l}\text { Insignificant number of deaths in children } \\
\text { Znikoma liczba zgonów dzieci }\end{array}$ \\
\hline G13 & $\begin{array}{l}\text { Systemic atrophies primarily affecting central } \\
\text { nervous system in diseases classified elsewhere } \\
\text { Zaniki układowe obejmujące pierwotnie } \\
\text { ośrodkowy układ nerwowy w przebiegu chorób } \\
\text { sklasyfikowanych gdzie indziej }\end{array}$ & $\begin{array}{l}\text { No child deaths } \\
\text { Brak zgonów dzieci }\end{array}$ \\
\hline G70 & $\begin{array}{l}\text { Myasthenia gravis and other myoneural disorders } \\
\text { Miastenia i inne zaburzenia nerwowo-mięśniowe }\end{array}$ & $\begin{array}{l}\text { Insignificant number of deaths in children } \\
\text { Znikoma liczba zgonów dzieci }\end{array}$ \\
\hline G73 & $\begin{array}{l}\text { Disorders of myoneural junction and muscle in } \\
\text { diseases classified elsewhere } \\
\text { Zaburzenia złącza mięśniowo-nerwowego } \\
\text { i mięśni w przebiegu chorób sklasyfikowanych } \\
\text { gdzie indziej }\end{array}$ & $\begin{array}{l}\text { No child deaths } \\
\text { Brak zgonów dzieci }\end{array}$ \\
\hline G81 & \begin{tabular}{|l|} 
Hemiplegia \\
Porażenie połowicze \\
\end{tabular} & \begin{tabular}{|l|} 
No child deaths \\
Brak zgonów dzieci \\
\end{tabular} \\
\hline G82 & $\begin{array}{l}\text { Paraplegia and tetraplegia } \\
\text { Porażenie kończyn dolnych i czterokończynowe }\end{array}$ & $\begin{array}{l}\text { No child deaths } \\
\text { Brak zgonów dzieci }\end{array}$ \\
\hline G83 & $\begin{array}{l}\text { Other paralytic syndromes } \\
\text { Inne zespoły porażenne }\end{array}$ & $\begin{array}{l}\text { Insignificant number of deaths in children } \\
\text { Znikoma liczba zgonów dzieci }\end{array}$ \\
\hline G90 & \begin{tabular}{|l|} 
Disorders of autonomic nervous system \\
Zaburzenia układu nerwowego wegetatywnego
\end{tabular} & $\begin{array}{l}\text { Insignificant number of deaths in children } \\
\text { Znikoma liczba zgonów dzieci }\end{array}$ \\
\hline G92 & $\begin{array}{l}\text { Toxic encephalopathy } \\
\text { Encefalopatia toksyczna }\end{array}$ & $\begin{array}{l}\text { Insignificant number of deaths in children } \\
\text { Znikoma liczba zgonów dzieci }\end{array}$ \\
\hline G93.0 & $\begin{array}{l}\text { Cerebral cysts } \\
\text { Torbiele mózgu }\end{array}$ & $\begin{array}{l}\text { Insignificant number of deaths in children } \\
\text { Znikoma liczba zgonów dzieci }\end{array}$ \\
\hline G93.2 & $\begin{array}{l}\text { Benign intracranial hypertension } \\
\text { Łagodne nadciśnienie wewnątrzczaszkowe }\end{array}$ & $\begin{array}{l}\text { No child deaths } \\
\text { Brak zgonów dzieci }\end{array}$ \\
\hline G93.3 & $\begin{array}{l}\text { Postviral fatigue syndrome } \\
\text { Zespół zmęczenia po zakażeniach wirusowych }\end{array}$ & $\begin{array}{l}\text { No child deaths } \\
\text { Brak zgonów dzieci }\end{array}$ \\
\hline G93.5 & $\begin{array}{l}\text { Compression of brain } \\
\text { Zespół uciskowy mózgu }\end{array}$ & $\begin{array}{l}\text { Immediate cause of death } \\
\text { Bezpośrednia przyczyna zgonu }\end{array}$ \\
\hline G93.6 & $\begin{array}{l}\text { Cerebral oedema } \\
\text { Obrzęk mózgu }\end{array}$ & $\begin{array}{l}\text { Secondary symptom requiring treatment in } \\
\text { a hospital } \\
\text { Objaw wtórny wymagający leczenia w szpitalu }\end{array}$ \\
\hline G93.7 & $\begin{array}{l}\text { Reye syndrome } \\
\text { Zespół Reye'a }\end{array}$ & $\begin{array}{l}\text { Requires treatment in a hospital (intensive care) } \\
\text { Wymaga leczenia w szpitalu (intensywna terapia) }\end{array}$ \\
\hline G93.8 & $\begin{array}{l}\text { Other specified disorders of brain } \\
\text { Inne określone zaburzenia mózgu }\end{array}$ & $\begin{array}{l}\text { Insignificant number of deaths in children } \\
\text { Znikoma liczba zgonów dzieci }\end{array}$ \\
\hline G94 & $\begin{array}{l}\text { Other disorders of brain in diseases classified } \\
\text { elsewhere } \\
\text { Inne patologie mózgu w przebiegu chorób } \\
\text { sklasyfikowanych gdzie indziej }\end{array}$ & $\begin{array}{l}\text { No child deaths } \\
\text { Brak zgonów dzieci }\end{array}$ \\
\hline G95 & $\begin{array}{l}\text { Other diseases of spinal cord } \\
\text { Inne choroby rdzenia kręgowego }\end{array}$ & $\begin{array}{l}\text { Insignificant number of deaths in children } \\
\text { Znikoma liczba zgonów dzieci }\end{array}$ \\
\hline
\end{tabular}




\begin{tabular}{|c|c|c|}
\hline & $\begin{array}{l}\text { Medical condition } \\
\text { Schorzenie }\end{array}$ & Reasons for rejection \\
\hline $\begin{array}{l}\text { ICD-10 codes } \\
\text { Kody ICD-10 }\end{array}$ & $\begin{array}{l}\text { Description } \\
\text { Opis }\end{array}$ & Przyczyny odrzucenia \\
\hline G96.0-G96.8 & $\begin{array}{l}\text { Other disorders of central nervous system } \\
\text { Inne zaburzenia ośrodkowego układu nerwowego }\end{array}$ & $\begin{array}{l}\text { Insignificant number of deaths in children } \\
\text { Znikoma liczba zgonów dzieci }\end{array}$ \\
\hline G96.9 & $\begin{array}{l}\text { Disorder of central nervous system, unspecified } \\
\text { Zaburzenia ośrodkowego układu nerwowego, } \\
\text { nieokreślone }\end{array}$ & $\begin{array}{l}\text { Insufficient diagnosis to initiate } \mathrm{PHC} \\
\text { Rozpoznanie niewystarczające do rozpoczęcia } \\
\text { OPH }\end{array}$ \\
\hline G97 & $\begin{array}{l}\text { Postprocedural disorders of nervous system, not } \\
\text { elsewhere classified } \\
\text { Pozabiegowe zaburzenia układu nerwowego, } \\
\text { niesklasyfikowane gdzie indziej }\end{array}$ & $\begin{array}{l}\text { No child deaths } \\
\text { Brak zgonów dzieci }\end{array}$ \\
\hline G98 & $\begin{array}{l}\text { Other disorders of nervous system, not elsewhere } \\
\text { classified } \\
\text { Inne zaburzenia układu nerwowego } \\
\text { niesklasyfikowane gdzie indziej }\end{array}$ & $\begin{array}{l}\text { Insufficient diagnosis to initiate PHC } \\
\text { Rozpoznanie niewystarczające do rozpoczęcia } \\
\text { OPH }\end{array}$ \\
\hline G99 & $\begin{array}{l}\text { Other disorders of nervous system in diseases } \\
\text { classified elsewhere } \\
\text { Inne zaburzenia układu nerwowego, występujące } \\
\text { w przebiegu chorób sklasyfikowanych gdzie } \\
\text { indziej }\end{array}$ & $\begin{array}{l}\text { No child deaths } \\
\text { Brak zgonów dzieci }\end{array}$ \\
\hline K74 & $\begin{array}{l}\text { Fibrosis and cirrhosis of liver } \\
\text { Zwłóknienie i marskość wątroby }\end{array}$ & $\begin{array}{l}\text { Indication for liver transplantation, not } \mathrm{PHC} \\
\text { Wskazanie do przeszczepienia wątroby, a nie } \mathrm{OPH}\end{array}$ \\
\hline P11.3 & $\begin{array}{l}\text { Birth injury to facial nerve } \\
\text { Uraz porodowy nerwu twarzowego }\end{array}$ & $\begin{array}{l}\text { No child deaths } \\
\text { Brak zgonów dzieci }\end{array}$ \\
\hline P11.4 & $\begin{array}{l}\text { Birth injury to other cranial nerves } \\
\text { Uraz porodowy innych nerwów czaszkowych }\end{array}$ & $\begin{array}{l}\text { No child deaths } \\
\text { Brak zgonów dzieci }\end{array}$ \\
\hline P11.5 & $\begin{array}{l}\text { Birth injury to spine and spinal cord } \\
\text { Uraz porodowy kręgosłupa i rdzenia kręgowego }\end{array}$ & $\begin{array}{l}\text { No child deaths } \\
\text { Brak zgonów dzieci }\end{array}$ \\
\hline P35.0 & $\begin{array}{l}\text { Congenital rubella syndrome } \\
\text { Wrodzony zespół różyczkowy }\end{array}$ & $\begin{array}{l}\text { Insignificant number of deaths in children; long- } \\
\text { term care } \\
\text { Znikoma liczba zgonów dzieci; opieka } \\
\text { długoterminowa }\end{array}$ \\
\hline P35.2 & $\begin{array}{l}\text { Congenital herpesviral [herpes simplex] infection } \\
\text { Wrodzone zakażenie wywołane przez wirus } \\
\text { opryszczki [herpes simplex] }\end{array}$ & $\begin{array}{l}\text { Insignificant number of deaths in children } \\
\text { Znikoma liczba zgonów dzieci }\end{array}$ \\
\hline P35.3 & $\begin{array}{l}\text { Congenital viral hepatitis } \\
\text { Wrodzone wirusowe zapalenie wątroby }\end{array}$ & $\begin{array}{l}\text { No child deaths } \\
\text { Brak zgonów dzieci }\end{array}$ \\
\hline Q04.4 & $\begin{array}{l}\text { Septo-optic dysplasia } \\
\text { Dysplazja przegrodowo-oczna }\end{array}$ & $\begin{array}{l}\text { No child deaths } \\
\text { Brak zgonów dzieci }\end{array}$ \\
\hline Q06.2 & $\begin{array}{l}\text { Diastematomyelia } \\
\text { Rozdwojenie rdzenia kręgowego }\end{array}$ & $\begin{array}{l}\text { No child deaths } \\
\text { Brak zgonów dzieci }\end{array}$ \\
\hline Q06.3 & $\begin{array}{l}\text { Other congenital cauda equina malformations } \\
\text { Inne wrodzone wady rozwojowe ogona końskiego }\end{array}$ & $\begin{array}{l}\text { No child deaths } \\
\text { Brak zgonów dzieci }\end{array}$ \\
\hline Q06.4 & $\begin{array}{l}\text { Hydromyelia } \\
\text { Wodordzenie }\end{array}$ & $\begin{array}{l}\text { No child deaths } \\
\text { Brak zgonów dzieci }\end{array}$ \\
\hline $\mathrm{Q} 24.0$ & $\begin{array}{l}\text { Dextrocardia } \\
\text { Prawostronne położenie serca }\end{array}$ & $\begin{array}{l}\text { Insignificant number of deaths in children } \\
\text { Znikoma liczba zgonów dzieci }\end{array}$ \\
\hline Q24.1 & $\begin{array}{l}\text { Laevocardia } \\
\text { Lewostronne położenie serca }\end{array}$ & $\begin{array}{l}\text { Insignificant number of deaths in children } \\
\text { Znikoma liczba zgonów dzieci }\end{array}$ \\
\hline Q25.0 & $\begin{array}{l}\text { Patent ductus arteriosus } \\
\text { Drożny przewód tętniczy }\end{array}$ & $\begin{array}{l}\text { Mild defect (does not require PHC) } \\
\text { Łagodna wada (nie wymaga OPH) }\end{array}$ \\
\hline
\end{tabular}




\begin{tabular}{|c|c|c|}
\hline \multicolumn{2}{|r|}{$\begin{array}{l}\text { Medical condition } \\
\text { Schorzenie }\end{array}$} & \multirow{2}{*}{$\begin{array}{l}\text { Reasons for rejection } \\
\text { Przyczyny odrzucenia }\end{array}$} \\
\hline $\begin{array}{l}\text { ICD-10 codes } \\
\text { Kody ICD-10 }\end{array}$ & $\begin{array}{l}\text { Description } \\
\text { Opis }\end{array}$ & \\
\hline Q31 & $\begin{array}{l}\text { Congenital malformations of larynx } \\
\text { Wrodzone wady rozwojowe krtani }\end{array}$ & $\begin{array}{l}\text { Defects requiring laryngological treatment; } \\
\text { a tracheostomy is not an indication for PHC } \\
\text { Wady wymagające leczenia laryngologicznego; } \\
\text { tracheostomia nie stanowi wskazania do OPH }\end{array}$ \\
\hline Q32 & $\begin{array}{l}\text { Congenital malformations of trachea and } \\
\text { bronchus } \\
\text { Wrodzone wady rozwojowe tchawicy i oskrzeli }\end{array}$ & $\begin{array}{l}\text { Defects requiring surgical treatment; } \\
\text { a tracheostomy is not an indication for PHC } \\
\text { Wady wymagające leczenia chirurgicznego; } \\
\text { tracheostomia nie stanowi wskazania do OPH }\end{array}$ \\
\hline Q60.0 & $\begin{array}{l}\text { Renal agenesis, unilateral } \\
\text { Agenezja nerki, jednostronna }\end{array}$ & $\begin{array}{l}\text { Insignificant number of deaths in children } \\
\text { Znikoma liczba zgonów dzieci }\end{array}$ \\
\hline Q60.2 & $\begin{array}{l}\text { Renal agenesis, unspecified } \\
\text { Agenezja nerki, nieokreślona }\end{array}$ & $\begin{array}{l}\text { Insignificant number of deaths in children } \\
\text { Znikoma liczba zgonów dzieci }\end{array}$ \\
\hline Q60.3 & $\begin{array}{l}\text { Renal hypoplasia, unilateral } \\
\text { Niedorozwój nerki, jednostronny }\end{array}$ & $\begin{array}{l}\text { Insignificant number of deaths in children } \\
\text { Znikoma liczba zgonów dzieci }\end{array}$ \\
\hline Q60.5 & \begin{tabular}{|l|} 
Renal hypoplasia, unspecified \\
Niedorozwój nerki, nieokreślony
\end{tabular} & $\begin{array}{l}\text { Insignificant number of deaths in children } \\
\text { Znikoma liczba zgonów dzieci }\end{array}$ \\
\hline Q78.1-Q78.9 & $\begin{array}{l}\text { Other osteochondrodysplasias } \\
\text { Inne osteochondrodysplazje }\end{array}$ & $\begin{array}{l}\text { Insignificant number of deaths in children } \\
\text { Znikoma liczba zgonów dzieci }\end{array}$ \\
\hline Q79 & $\begin{array}{l}\text { Congenital malformations of the musculoskeletal } \\
\text { system, not elsewhere classified } \\
\text { Wrodzone wady rozwojowe układu mieśniowo- } \\
\text { szkieletowego, niesklasyfikowane gdzie indziej }\end{array}$ & $\begin{array}{l}\text { Defects requiring surgical treatment, not PHC } \\
\text { Wady wymagające leczenia chirurgicznego, a nie } \\
\text { OPH }\end{array}$ \\
\hline Q81.0 & $\begin{array}{l}\text { Epidermolysis bullosa simplex } \\
\text { Pęcherzowe oddzielanie naskórka proste }\end{array}$ & $\begin{array}{l}\text { Insignificant number of deaths in children } \\
\text { Znikoma liczba zgonów dzieci }\end{array}$ \\
\hline Q81.2 & $\begin{array}{l}\text { Epidermolysis bullosa dystrophica } \\
\text { Pęcherzowe oddzielanie naskórka postać } \\
\text { dystroficzna }\end{array}$ & $\begin{array}{l}\text { Insignificant number of deaths in children } \\
\text { Znikoma liczba zgonów dzieci }\end{array}$ \\
\hline Q81.8 & $\begin{array}{l}\text { Other epidermolysis bullosa } \\
\text { Inne oddzielanie pęcherzowe naskórka }\end{array}$ & $\begin{array}{l}\text { Insignificant number of deaths in children } \\
\text { Znikoma liczba zgonów dzieci }\end{array}$ \\
\hline Q81.9 & $\begin{array}{l}\text { Epidermolysis bullosa, unspecified } \\
\text { Pęcherzowe oddzielanie naskórka, nieokreślone }\end{array}$ & $\begin{array}{l}\text { Child deaths encoded in this way are likely } \\
\text { epidermolysis bullosa letalis, i.e. Q81.1 } \\
\text { Zgony dzieci kodowane w ten sposób to } \\
\text { prawdopodobnie pęcherzowe oddzielanie } \\
\text { naskórka, postać śmiertelna, czyli Q81.1 }\end{array}$ \\
\hline Q89.0 & $\begin{array}{l}\text { Congenital malformations of spleen } \\
\text { Wrodzone wady rozwojowe śledziony }\end{array}$ & $\begin{array}{l}\text { Insignificant number of deaths in children } \\
\text { Znikoma liczba zgonów dzieci }\end{array}$ \\
\hline Q89.1 & $\begin{array}{l}\text { Congenital malformations of adrenal gland } \\
\text { Wrodzone wady rozwojowe nadnerczy }\end{array}$ & $\begin{array}{l}\text { Insignificant number of deaths in children } \\
\text { Znikoma liczba zgonów dzieci }\end{array}$ \\
\hline Q89.2 & $\begin{array}{l}\text { Congenital malformations of other endocrine } \\
\text { glands } \\
\text { Wrodzone wady rozwojowe innych gruczołów } \\
\text { wydzielania wewnętrznego }\end{array}$ & $\begin{array}{l}\text { Insignificant number of deaths in children } \\
\text { Znikoma liczba zgonów dzieci }\end{array}$ \\
\hline Q89.3 & $\begin{array}{l}\text { Situs inversus } \\
\text { Ułożenie odwrotne }\end{array}$ & $\begin{array}{l}\text { Insignificant number of deaths in children } \\
\text { Znikoma liczba zgonów dzieci }\end{array}$ \\
\hline Q89.8 & $\begin{array}{l}\text { Multiple congenital malformations, not elsewhere } \\
\text { classified } \\
\text { Inne określone wrodzone wady rozwojowe }\end{array}$ & $\begin{array}{l}\text { The diagnosis is too general to be considered an } \\
\text { indication for PHC } \\
\text { Rozpoznanie zbyt ogólnikowe, by uznać je za } \\
\text { wskazanie do OPH }\end{array}$ \\
\hline Q95 & $\begin{array}{l}\text { Balanced rearrangements and structural markers, } \\
\text { not elsewhere classified } \\
\text { Zrównoważone przemieszczenie materiału } \\
\text { genetycznego i znaczniki strukturalne, } \\
\text { niesklasyfikowane gdzie indziej }\end{array}$ & $\begin{array}{l}\text { Insignificant number of deaths in children } \\
\text { Znikoma liczba zgonów dzieci }\end{array}$ \\
\hline
\end{tabular}




\begin{tabular}{|c|c|c|}
\hline \multicolumn{2}{|r|}{$\begin{array}{l}\text { Medical condition } \\
\text { Schorzenie }\end{array}$} & \multirow{2}{*}{$\begin{array}{l}\text { Reasons for rejection } \\
\text { Przyczyny odrzucenia }\end{array}$} \\
\hline $\begin{array}{l}\text { ICD-10 codes } \\
\text { Kody ICD-10 }\end{array}$ & $\begin{array}{c}\text { Description } \\
\text { Opis }\end{array}$ & \\
\hline Q96 & $\begin{array}{l}\text { Turner syndrome } \\
\text { Zespół Turnera }\end{array}$ & $\begin{array}{l}\text { Insignificant number of deaths in children } \\
\text { Znikoma liczba zgonów dzieci }\end{array}$ \\
\hline Q97 & $\begin{array}{l}\text { Other sex chromosome abnormalities, female } \\
\text { phenotype, not elsewhere classified } \\
\text { Inne aberracje chromosomów płciowych } \\
\text { z fenotypem żeńskim, niesklasyfikowane gdzie } \\
\text { indziej }\end{array}$ & $\begin{array}{l}\text { Insignificant number of deaths in children } \\
\text { Znikoma liczba zgonów dzieci }\end{array}$ \\
\hline Q98 & $\begin{array}{l}\text { Other sex chromosome abnormalities, male } \\
\text { phenotype, not elsewhere classified } \\
\text { Inne aberracje chromosomów płciowych } \\
\text { z męskim fenotypem, niesklasyfikowane gdzie } \\
\text { indziej }\end{array}$ & $\begin{array}{l}\text { Insignificant number of deaths in children } \\
\text { Insignificant number of deaths in children } \\
\text { Znikoma liczba zgonów dzieci }\end{array}$ \\
\hline Q99.0 & $\begin{array}{l}\text { Chimera 46,XX/46,XY } \\
\text { Chimera 46, XX / 46, XY }\end{array}$ & $\begin{array}{l}\text { Insignificant number of deaths in children } \\
\text { Znikoma liczba zgonów dzieci }\end{array}$ \\
\hline Q99.1 & $\begin{array}{l}\text { Chimer 46,XX true hermaphrodite } \\
\text { Chimera } 46, \mathrm{XX} / 46, \mathrm{XY} \text { z obojnactwem } \\
\text { prawdziwym }\end{array}$ & $\begin{array}{l}\text { Insignificant number of deaths in children } \\
\text { Znikoma liczba zgonów dzieci }\end{array}$ \\
\hline Q99.2 & $\begin{array}{l}\text { Fragile } X \text { chromosome } \\
\text { Łamliwy chromosom } X\end{array}$ & $\begin{array}{l}\text { Insignificant number of deaths in children } \\
\text { Znikoma liczba zgonów dzieci }\end{array}$ \\
\hline T90 & $\begin{array}{l}\text { Sequelae of injuries of head } \\
\text { Następstwa urazów głowy }\end{array}$ & $\begin{array}{l}\text { No child deaths; code appropriate for PHC - S06.7 } \\
\text { Intracranial injury with prolonged coma } \\
\text { Brak zgonów dzieci; kod właściwy dla OPH } \\
\text { - S06.7 Uraz śródczaszkowy z długotrwałym } \\
\text { okresem nieprzytomności }\end{array}$ \\
\hline T91 & Następstwa urazów szyi i tułowia & $\begin{array}{l}\text { No child deaths } \\
\text { Brak zgonów dzieci }\end{array}$ \\
\hline T94 & $\begin{array}{l}\text { Następstwa urazów obejmujących liczne okolice } \\
\text { ciała i nieokreślone okolice ciała }\end{array}$ & $\begin{array}{l}\text { No child deaths } \\
\text { Brak zgonów dzieci }\end{array}$ \\
\hline T96 & $\begin{array}{l}\text { Następstwa zatrucia lekami, środkami } \\
\text { farmakologicznymi i substancjami biologicznymi }\end{array}$ & $\begin{array}{l}\text { No child deaths } \\
\text { Brak zgonów dzieci }\end{array}$ \\
\hline T97 & $\begin{array}{l}\text { Następstwa toksycznych skutków działania } \\
\text { substancji zazwyczaj niestosowanych w celach } \\
\text { leczniczych }\end{array}$ & $\begin{array}{l}\text { No child deaths } \\
\text { Brak zgonów dzieci }\end{array}$ \\
\hline Y89 & $\begin{array}{l}\text { Następstwa działania innych przyczyn } \\
\text { zewnętrznych }\end{array}$ & $\begin{array}{l}\text { The diagnosis is too general to be considered an } \\
\text { indication for PHC } \\
\text { Rozpoznanie zbyt ogólnikowe, by uznać je za } \\
\text { wskazanie do OPH }\end{array}$ \\
\hline
\end{tabular}

SCC applied to the Minister of Health for a development of standards of conduct and medical procedures in the field of PHC, stating that there was no justification for the Minister's inaction in drawing up the standards (3). Despite this, the draft of FWHD standards were not adopted (until January 2021).

\section{CONCLUSIONS}

1. The Regulation of the Minister of Health necessitates an amendment regarding the list of medical conditions entitling children to guaranteed palliative care and hospice services.
Kryteria kwalifikacji do PedOP oraz wypisywania pacjentów $\mathrm{z}$ hospicjum domowego dla dzieci, ponadto definicje PedOP i pediatrycznej opieki długoterminowej oraz kryteria je różnicujące, zostały opublikowane w projekcie standardów FWHD (1).

NIK wystąpiła do Ministra Zdrowia o opracowanie standardów postępowania i procedur medycznych z zakresu OPH, stwierdzając, że nie znajduje uzasadnienia dla bezczynności Ministra w opracowaniu standardów (3). Pomimo tego projekt standardów FWHD nie został przyjęty (do stycznia $2021 \mathrm{r}$.). 
2. The Minister of Health should introduce standards and medical procedures for pediatric palliative care.

3. Patients should be recruited on the basis of recognized standards by physicians and not officials of the National Health Fund using incomplete and inadequate Minister of Health's catalogue of medical conditions.

4. International Classification of Diseases, $10^{\text {th }}$ Revision does not cover all medical conditions that may require pediatric palliative care. From 2022 , it is necessary to make use of the ICD-11 Classification (9).

\section{ACKNOWLEDGEMENTS}

The authors thank Prof. Ryszard Grenda, Dr. Marek Karwacki, Dr. Beata Kościańska, Prof. Janusz Szymborski and Prof. Joanna Szymkiewicz-Dangel for the scientific consultation, and the Warsaw Hospice for Children Foundation for funding the study.

\section{REFERENCES}

1. Dangel T (red.), i in. Standardy postępowania i procedury medyczne pediatrycznej domowej opieki paliatywnej w hospicjach dla dzieci. Wyd 4. Standardy perinatalnej opieki paliatywnej. Wyd 1. Warszawa: Fundacja Warszawskie Hospicjum dla Dzieci; 2019: strona 25-27,30-32.https://hospicjum. waw.pl/pliki/Artyku1/1489_Standardy-2019.pdf

2. Dangel T, Szamotulska K, Wojciechowska U. Zapotrzebowanie na opiekę paliatywną nad dziećmi w Polsce - analiza epidemiologiczna. Pediatr Pol 2000;9:695-707.

3. Najwyższa Izba Kontroli. Zapewnienie opieki paliatywnej i hospicyjnej. Informacja o wynikach kontroli. NIK; 2019: strona 18, 21. https://www. nik.gov.pl/plik/id,21371,vp,24011.pdf

4. Rozporządzenie Ministra Zdrowia z dnia 29 października 2013 r. $\quad$ w sprawie świadczeń gwarantowanych z zakresu opieki paliatywnej i hospicyjnej. Załącznik 1/II str. 6-8. http:// prawo.sejm.gov.pl/isap.nsf/download.xsp/ WDU20180000742/O/D20180742.pdf

5. Kozera K, Wojciechowska U, Marciniak W, Tokarska E, Dangel T. Pediatryczna domowa opieka paliatywna Polsce (2013). Medycyna Paliatywna 2015;7:9-44. https://hospicjum.waw. pl/pliki/Artykul/1109 pediatryczna-domowaopieka-paliatywna-w-polsce-2013.pdf

6. Integrating palliative care and symptom relief into paediatrics: a WHO guide for health care planners, implementers and managers. World Health Organization 2018: strona 5. https://apps.who.int/iris/ bitstream/handle/10665/274561/9789241514453eng.pdf?ua $=1$

\section{WNIOSKI}

1. Rozporządzenie Ministra Zdrowia wymaga nowelizacji w zakresie wykazu jednostek chorobowych kwalifikujących dzieci do świadczeń gwarantowanych z zakresu opieki paliatywnej i hospicyjnej.

2. Minister Zdrowia powinien wprowadzić standardy postępowania i procedury medyczne pediatrycznej opieki paliatywnej.

3. O kwalifikacji pacjentów do pediatrycznej opieki paliatywnej powinni decydować lekarze na podstawie obowiązujących standardów, a nie urzędnicy Narodowego Funduszu Zdrowia na podstawie niekompletnego i nieadekwatnego katalogu schorzeń.

4. Klasyfikacja ICD-10 nie pozwala na opisanie wszystkich schorzeń, które mogą wymagać pediatrycznej opieki paliatywnej. Od 2022 r. należy posiłkować się Klasyfikacją ICD-11 (9).

\section{PODZIĘKOWANIE}

Autorzy dziękują za konsultację naukową prof. dr. hab. n. med. Ryszardowi Grendzie, dr. n. med. Markowi Karwackiemu, dr. n. med. Beacie Kościańskiej, prof. dr. hab. n. med. Januszowi Szymborskiemu i prof. dr. hab. n. med. Joannie Szymkiewicz-Dangel oraz Fundacji Warszawskie Hospicjum dla Dzieci za sfinansowanie badania.

7. Dangel $\mathrm{T}$ (red.), et al. Zaniechanie i wycofanie się $\mathrm{z}$ uporczywego leczenia podtrzymującego życie u dzieci - wytyczne dla lekarzy. Wyd 1. Warszawa: Polskie Towarzystwo Pediatryczne; 2011: strona 40. https://hospicjum.waw.pl/pliki/Artykul/1134_ zaniechanieiwycofaniezleczeniapodtrzymujacego zycieudzieci-wytyczneptp-2011.pdf

8. Hoell JI, Warfsmann J, Gagnon G, i in. Palliative care for children with a yet undiagnosed syndrome. Eur J Pediatr 2017;176:1319-27.

9. International Classification of Diseases for Mortality and Morbidity Statistics. ICD-11 MMS. World Health Organization 2019.

Received: 19.06.2020

Otrzymano: 19.06.2020 r.

Accepted for publication: 21.10.2020

Zaakceptowano do publikacji: $21.10 .2020 \mathrm{r}$.

\section{Address for correspondence: Adres do korespondencji:}

Tomasz Dangel

Fundacja Warszawskie Hospicjum dla Dzieci

ul. Agatowa 10. 03-680 Warszawa

telefon: 048502088368

e-mail: dangel@hospicjum.waw.pl

ORCID 0000-0002-3664-1411 